International Review of Social History 45 (2000), pp. 409-448

(C) 2000 Internationaal Instituut voor Sociale Geschiedenis

\title{
Repertoires of Coercion and Market Culture in Nineteenth-Century Buenos Aires Province
}

\author{
Ricardo D. SAlvatore
}

Summary: During the post-Independence period, Buenos Aires province engaged in a republican-authoritarian experiment in which the relations between dominant and subaltern were altered and redefined. The ascent to power of Juan Manuel de Rosas and the federalists meant an increase in the violence meted out by the state against its political and military opponents. On the other hand, the diffusion of a market economy created the basis of contractual relations across a variety of social fields and institutions. This was true with regard to relations between masters and servants in the household, between officers and soldiers within regiments, between rural residents and justices of the peace, between ranchers and peons at the estancia. Though coercion did not disappear, the power to coerce found limits because of the very expansion of market relations. To address these changes, in their complexity and diversity, this article uses the concept "repertoires of coercion". The concept may be useful to analyze and compare relations of power in multiple social or institutional spaces. In addition, the article addresses the question of the relationship between coercion and market culture, suggesting that in a situation of labor scarcity, and the military mobilization of the subaltern classes, contractualism tends to pervade relations of power, even those previously based upon coercion.

During the period $\mathrm{I} 820-\mathrm{I} 865$, Buenos Aires province was not a fertile terrain for the most typical forms of coerced labor (debt peonage, slavery, indentured servitude, convict labor). Instead, a variety of contractual arrangements (wage labor, sharecropping, tenancy) developed around the production of jerked beef, hides, tallow, and wool for export. ${ }^{\text {I }}$ A society with low population density, chronic shortages of labor, and intense occupational and geographical labor mobility generated the conditions for active markets in labor power. Unable to restrain rural laborers through indebtedness or direct coercion, landowners learned to accept the logic of the market: to attract peons they had to offer competitive wages. ${ }^{2}$ This "free labor"

I. Even as a "free-labor" society, post-Independence Buenos Aires province was rather peculiar. It did not have anything resembling a "master and servant" law (the conchavo laws being a rather distant relative) and it lacked true experience in guild regulations.

2. I have developed this argument in R. Salvatore, "Modes of Labor Control in Cattle-Ranching Economies: California, Southern Brazil, and Argentina, I820-I860", Journal of Economic History, 5I (I99I), pp. 44I-45I; and "Autocratic State and Labor Control in the Argentine Pampas: Buenos Aires, I829-I852”, Peasant Studies, I8 (199I), pp. 25I-278. 


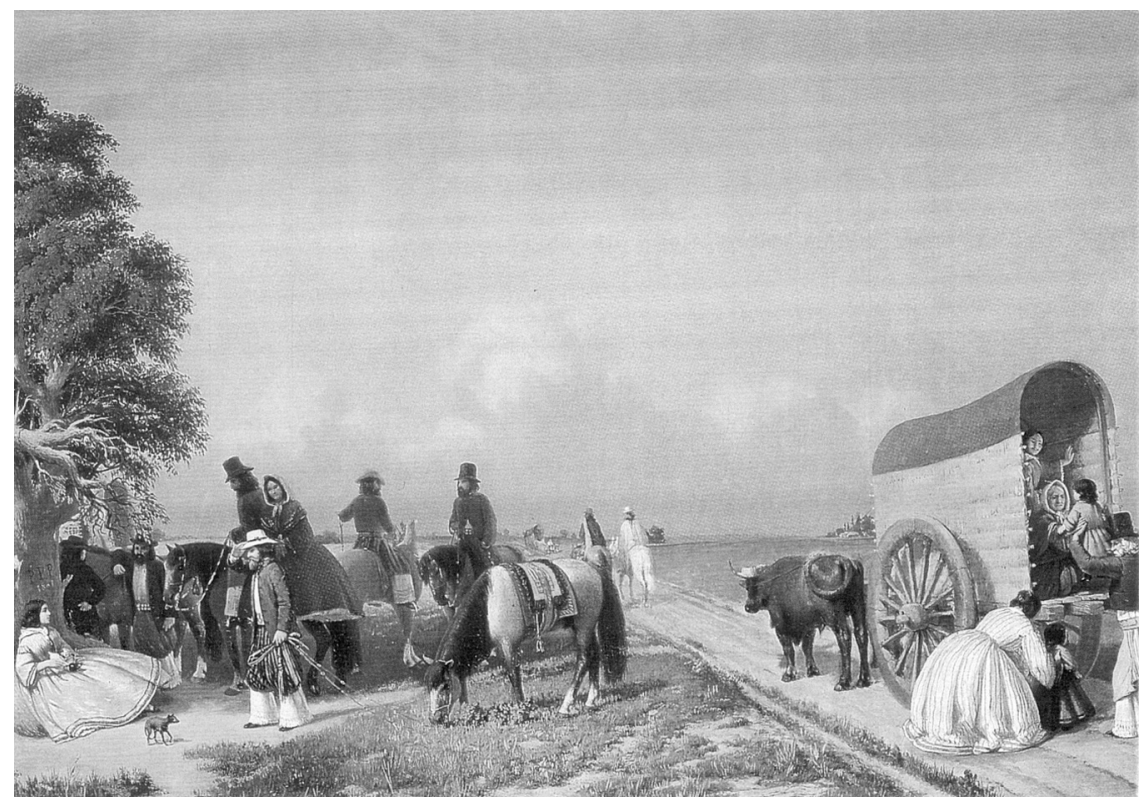

Figure I. Prilidiano Pueyrredón, Un Alto en el Campo, (oil on canvas, I850s). After the Fall of Rosas, the expansion of the rural economy created prosperity. Here the painter captured the harmonious sociability of a market society. Well-dressed, well-mannered, and engaged in polite conversation, small property owners seem to be enjoying their regained "freedom".

Asociación de Amigos del Museo Nacional de Bellas Artes, Buenos Aires

society, however, was not devoid of coercion, for the formation of the national state demanded masses of involuntary soldiers, constant intimidatory raids against indigenous peoples, and the violent suppression of political opponents. The construction of social order translated into the incarceration of black servants, the public execution of delinquents, the "dumping" of unfaithful or insubordinate wives, and an array of other forms of violence.

The adoption of liberal political institutions by the post-Independence leadership, the gradual abolition of slavery (through manumission and outcontracting), and the rapid diffusion of wage labor, have tended to obscure the degree and diversity of coercion in this formative period of the Argentine Confederation. ${ }^{3}$ Liberal historians have privileged the study of

3. On the prevalence of wage labor vis-á-vis slave labor in Buenos Aires province from the late colonial period see Lyman L. Johnson, "The Competition of Slave and Free Labor in Artisanal Production: Buenos Aires, 1770-1815", International Review of Social History, 40 (1995), pp. 409424; Samuel Amaral, "Rural Production and Labour in Late Colonial Buenos Aires", Journal of Latin American Studies, 19 (1987), pp. 235-278; and Ricardo Salvatore and Jonathan C. Brown, "Trade and Proletarianization in Late Colonial Banda Oriental", Hispanic American Historical Review, 67 (1987), pp. 43I-459. Carlos Mayo believes that a free market for rural workers had 
political violence - particularly that directed against the literate classes, or gente decente - over any other type of coercion. Historians of estancias (ranches) and gauchos (cowboys) have contributed to the confusion, posing the persistence of certain mechanisms for restricting the mobility of rural workers as the most important and regrettable legacy of nineteenth-century Argentina. ${ }^{4}$ Thus, political violence and the victimization of rural laborers remained as the two most enduring themes of post-Independence historical narratives. Both types of histories have overlooked important forms of violence exerted over Africans, indigenous peoples, women, and children. Furthermore, the historiography has minimized the incidence of the most widespread form of state coercion during this period: forced militarization. ${ }^{5}$

To reconstruct the dynamics of domination and resistance during this period, we need a more comprehensive view of coercion. Recent studies on Afro-Argentines, soldiers, families, and captives have added new dimensions to the problem of domination and resistance. Yet we still lack a more general understanding of the diversity, intensity, and evolution of coercive power in nineteenth-century Argentina. ${ }^{6}$ Presenting such a comprehensive view demands an effort in terms of description - other coercive situations must be inserted into the traditional narrative of the post-Independence period as well as a determination to tackle the difficult issue of comparability. Was the restriction on the mobility of peons a more important form of coercion than the violence suffered by Afro-Argentines in their relations with masters?

already emerged in the period 1740-1820: Carlos Mayo, Estancia y sociedad en la pampa, 1740I820 (Buenos Aires, 1995), ch. 6.

4. An influential interpretation portrays the fate of the popular sectors as the perpetual victims of state and terrateniente coercion. A series of legislative acts criminalizing the activities and condition of the poor (vagrancy laws, passport laws, rural codes, etc.) compounded the private violence exerted by landowners in the domain of their ranches to deprive the poor of property and liberty. In other words, these authors assert that the transition from the colonial to the late nineteenthcentury order entailed the persistence of the same level of coercion against the popular sectors. The emergence of market culture brought no amelioration of the levels and range of coercion in society. See, for example, Ricardo Rodríguez Molas, Historia social del gaucho (Buenos Aires, 1968); Richard Slatta, Gauchos and the Vanishing Frontier (Lincoln, NB, 1983); Eduardo Ascuy Ameghino and G. Martínez Gougnac, Tierras y ganado en la campaña de Buenos Aires (Buenos Aires, 1989); John Lynch, Argentine Dictator (Oxford, I98I). As we shall see, this interpretation needs substantial revision.

5. Literature has paid more attention to these forms of violence than historians. The popular poem El Gaucho Martín Fierro, published in 1872 , dealt with the personal experience of a gaucho subject to the coercive power of justices, military officers, and ranchers.

6. See George Reid Andrews, The Afro-Argentines of Buenos Aires I800-1900 (Madison, WI, I980); Ricardo D. Salvatore, "Reclutamiento militar, disciplinamiento y proletarización en la era de Rosas", Boletin del Instituto Ravignani, 5 (1992), pp. 25-47; Susan Socolow, "Los cautivos españoles en las sociedades indígenas", Anuario IEHS, 2 (1987), pp. 99-136; Ricardo Cicerchia, "Vida familiar y prácticas conyugales. Clases populares en la ciudad colonial. Buenos Aires, I800-I8Io", Boletín del Instituto Ravignani, 3a serie, no. 2 (1989), pp. 9I-I09; and Mark D. Szuchman, Order, Family, and Community in Buenos Aires, I810-1860 (Stanford, CA, 1988). 
Was the violence generated by this society against women and children less intense than that directed against adult males? How does the intimidation and terrorizing of political dissidents compare with similar tactics employed against indigenous peoples?

The problem of devising means to compare situations of coercion, distributed across a variety of social fields or institutional contexts, is an important one. ${ }^{7}$ Before anything can be said about how coercion changed over time - its decline or increase in relation to the emergence and diffusion of market mechanisms and of a market culture - the diverse forms of this phenomenon need to be mapped and evaluated as a whole. Military, judicial, political, gender, racial and other types of coercion need to be placed in a comparative framework where their intensity and extension can be assessed and ordered, however imperfectly. While the comprehension of particular forms of domination demand special attention, our local and specialized histories have fragmented inordinately the historian's field of vision, making practically impossible general assessments about the evolution of coercion and freedom in a given society and time period. We need to tackle the question of comparability and devise means to aggregate different types of coercion.

Posing any intelligible answer to the question of the relationship between coercion and market culture demands an understanding of the diversity, modularity, and uneven diffusion of the forms of coercion and violence in a given society. ${ }^{8}$ This confronts the researcher with a difficult set of questions. How does one address the diversity of coercion? How can one be attentive to the multiple power situations from which coercion emerges? How can one compare the levels and intensities of violence in distinct environments and institutions? How does one elucidate the "mass" of coercive situations from the limited sample one finds in the archive? Should one make a distinction between attitudes towards coercion and the actual incidence of the latter??

In this article, I suggest the usefulness of the concept "repertoires of

7. For the concept of "social fields" see Pierre Bourdieu, The Logic of Practice (Stanford, CA, 1980). For a discussion see Craig Calhoum, "Habitus, Field, and Capital: The Question of Historical Specificity”, in Craig Calhoum et al. (eds), Bourdieu: Critical Perspectives (Chicago, IL, 1993), pp. 6I-88.

8. Perhaps we will never be able to construct a general index of coercion in which the different situations of violence can be contemplated and aggregated with their correct weights, for the incidence and diffusion of certain forms of coercion (against women and children, for example) will remain hidden from our view or their characteristics remain intractable to the statistician.

9. "Classical" accounts of domination and punishment (Durkheim, Weber) tend to consider whole societal "penal systems" or "modes of domination". My interest, on the other hand, is in fragmenting power, domination, and punishment into different fields of power, into different institutional contexts, into menus of concrete means of coercion. See David Garland, Punishment and Modern Society (Chicago, IL, I990), ch. 2; and Max Weber, Economía y Sociedad (Mexico City, 1944), vol. 2. 
coercion" to envision the multiple situations of violence that a society generates. A simple inventory of means of coercion at the disposal of a given set of dominant agents acting in certain institutional sites, repertoires of coercion provide us with a way of mapping the diffusion of coercion across society. Presented as a heuristic perspective more than as an analytical tool, the exercise of "mapping" coercive situations can, it is argued, help us "observe" the overall levels and intensity of the coercion under a given political regime, social formation, and culture. This approach privileges the enterprise of deploying multiple situations of coercion as a means to understand the dynamic of domination and resistance in all its diversity and multidimensionality. It also emphasizes the institutional embeddedness of coercive practices and the limits imposed by subaltern resistance. Underlying this approach is the idea that social fields and institutions have their own sets of rules and penalties for the attainment of their imagined orders, and that the enforcement of these rules and penalties generates a set of expected responses from subaltern subjects. In other words, that the conduct of war, the rearing of children, or the confinement of prisoners, "require" certain forms of coercion that "invite" certain types of resistance. Repertoires of coercion, the result of this dynamic between domination and resistance, represent a socially defined limit or boundary to the exercise of coercion. To historians, they provide a synthetic approximation to envision the question of coercion in all its diversity and complexity.

In this essay, I apply this concept to the multiple forms of violence prevalent in Buenos Aires province during the period 1820-1865. By mapping different situations of coercion in social fields such as the household, the private economy, the judicial system, politics, and white-Indian relations, it presents a more comprehensive view than hitherto attempted. The purpose of this exercise is threefold. First, I want to try to counter the centrality of certain forms of violence (political violence and landowners' labor control) in traditional historical narratives of the nation, by bringing into focus other situations of coercion. Secondly, I want to highlight the multidimensionality and complexity of coercion, and the contested nature of each coercive situation. Thirdly, the mapping provides a general view of the relative power of subaltern subjects in post-Independence Buenos Aires province. It is hoped that this way of presenting history might enhance our comprehension of the relationship between state order, market economy, and subaltern culture.

An additional objective of this paper is to discuss, in the light of these repertoires, the relationship between coercion and market culture in postIndependence Buenos Aires province. Necessarily, the plurality and contested nature of coercion brings us into the territory of contractual relationships and markets. In a society with high occupational and spatial mobility, "exiting" from coercive situations, and "voicing" grievances about illegitimate coercion were ever-present possibilities. This pushed dominant 


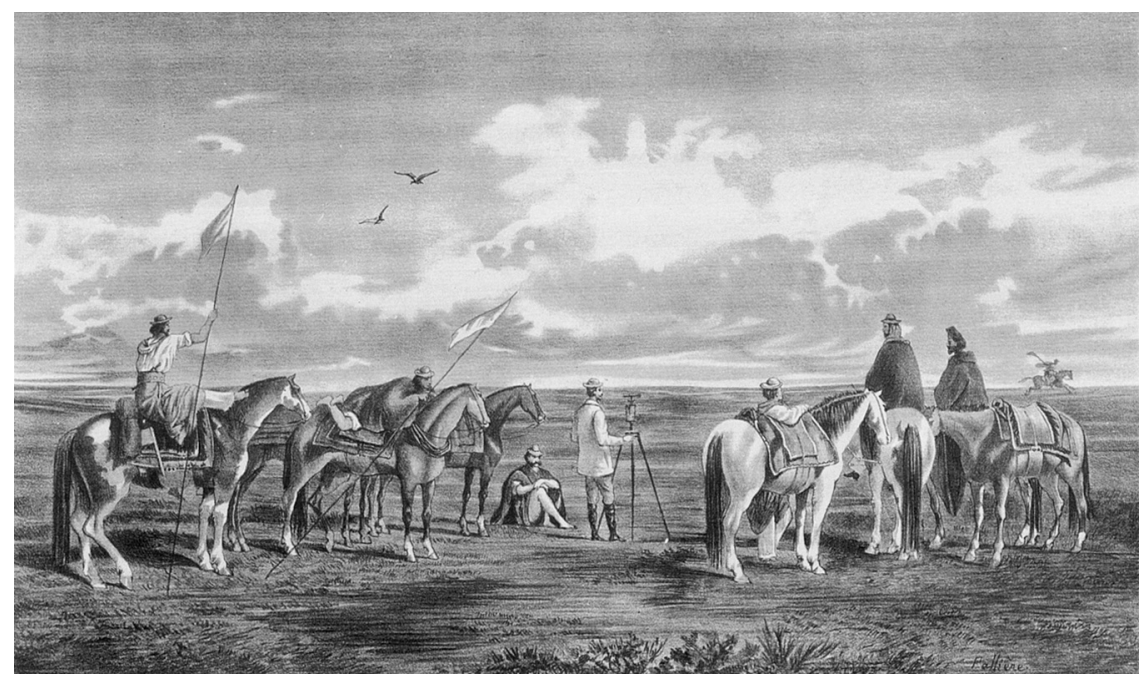

Figure 2. Leon Palliere El Agrimensor, (lithograph, I860s). Land surveys and the demarcation of property, as interpreted by Palliere, did not produce major reactions from "gauchos". The opening of new territories in the "frontier" expanded the employment and the wages of peons. In this scene, rural peons (one of them still wearing the Rosista headgear) cooperate with the land surveyor in the demarcation of property.

From Leon Palliere, Escenas Americanas (Buenos Aires: Litografia Pelvilain, I864)

subjects into situations in which they had to incorporate economic and other incentives as counterparts to coercive actions or threats. In this way, contractual arrangements and market incentives entered into the very negotiation of everyday life. Unable to keep populations under confinement for long periods of time (except, perhaps, for the army, the only institution with enough disciplinary muscle), most dominant subjects had to bend to the logic of the market, without abandoning coercive measures or threats completely.

In this regard, I will suggest that as long as Argentina remained a land of scarce labor (a situation typical of the whole period under consideration), coercion remained contested in various institutional and social fields and, most importantly, was always very close to contractual relations. Whether it was the household, the army, the judiciary, or the ranch, coercion always appeared to be accompanied by various types of incentive. In this arrangement of power, only political violence was non-negotiable; it offered no alternatives. To illustrate this argument (though not to prove it), I will be contributing some impressionistic evidence about the "attraction" of markets in coercive situations. It is in this general context of repertoires of coercion in relation to a contractual or market culture that I will situate a tentative explanation to the question of why nineteenth-century Argentina failed to develop any perdurable system of coerced labor. 


\section{REPERTOIRES OF COERCION}

In order to study the phenomenon we call coercion, without reducing its complexity, it is useful to think in terms of the sets of repertoires of coercion available to dominant actors within certain institutional contexts. Charles Tilly's concept of "repertoires of contention", a construct designed for the study of collective action, can be profitably extended to the analysis of coercion. Tilly uses this term to refer to "a limited set of routines that are learned, shared and acted out through a relatively deliberate process of choice", in order to make claims of different kinds on authorities or superiors. ${ }^{\text {Io }}$ Each epoch and regional context endows people with an array of forms with which to express their grievances, and with an experiential knowledge about which forms are more effective for each purpose. Out of a much larger pool of possible forms of collective action, people choose to express their grievances and claims using a limited set of forms - forms that, in time, become highly routinized. The "repertoire" represents, in an abridged manner, people's accumulated experience about the forms and effectiveness of collective action.

According to Tilly, people's repertoires of contention grow out of four main factors: popular daily routines and organization; prevailing standards of justice; popular experience with contention; and current patterns of repression. ${ }^{\text {II }}$ Confrontations brought about by the penetration of markets and state power in the social life of communities engendered a series of collective actions that, selected through experience, consolidated certain "repertoires of contention". Positioning ourselves on the other side of the dominant-subordinate relationship, we can argue that dominant actors also have a quite limited number of options with which to exercise coercion; and that ideological and legal forces, state imperatives, popular contention, and peer control restrict their domain of action vis-à-vis subaltern groups. Consequently, we can define repertoires of coercion as a whole set of means of coercion whose scope and diversity is determined by past experience. Institutions or power-holders learn through experience that coercion can be exercised through different means, some more effective than others.

At each historical conjuncture, dominant groups found themselves constrained by legal sanction, public morality, peer condemnation, or subaltern

IO. See Charles Tilly, "Contentious Repertoires in Great Britain, I758-1834", Center for Studies of Social Change, Working Paper no. I4I, (New York, I992); Charles Tilly, "Repertoires of Contention in America and Britain, 1750-1830", in Mayer N. Zald and John D. McCarthy (eds), The Dynamics of Social Movements (Cambridge, MA, 1979); and Charles Tilly, The Contentious French (Cambridge, MA, 1986). For a discussion of Tilly's concept see Sidney Tarrow, Power in Movement: Social Movements, Collective Action and Politics (New York, 1994), ch. 2. For an application of this construct to collective action in Latin American history, see David Sowell, "Repertoires of Contention in Urban Colombia, 1760s-1940s: An Inquiry into Latin American Social Violence", Journal of Urban History, 24 (1998), pp. 302-336.

II. Tilly, The Contentious French, p. Io. 
resistance to a limited choice of actions. In fact, I shall argue, because of these limitations, dominant groups often felt that they needed to combine coercion with persuasion and various types of incentive to achieve their objectives. Repertoires of coercion comprehend both the possibilities of administering coercive measures and the knowledge gained about the limits and effectiveness of such actions. ${ }^{12}$ Central to the experience upon which each "repertoire" is built, is the past dynamic of domination and resistance. The boundaries of coercion - the possibility of exercising a certain bundle of repressive or intimidatory actions - are shaped by prior experience of confrontation and by the informal and formal "rights" gained by subaltern subjects within a given social field.

Also important in framing the boundaries of the exercise of coercion are factors such as the existence, or otherwise, of modern institutions of confinement, the territorial and legal boundaries set by the nation state, the mobility of the population, and society's tolerance towards violence. In addition, discourses about the relative "weakness", "brutality", or intractability of certain subaltern subjects are crucial in shaping the consensus (among the dominant) about the necessity of and opportunity for coercion. Since subalternity as such is a socially and culturally defined location, the exercise of authority is always predicated upon notions of subjectivity (alterities) constructed by the dominant. Conceptions about "the right place" that women, children, slaves, colonials, and other subalterns should occupy in a given power relationship help to shape available repertoires of coercion. ${ }^{\mathrm{I}}$

In general, the repertoires of coercion available at a certain moment in time depend upon: (a) some technological, legal, and financial constraints defining the possibilities of applying certain forms of coercion; (b) the level of tolerance of society towards distinct forms of violence; (c) subaltern subjects' resistance in the form of an accumulated experience in dealing with the powerful, in particular with state institutions; (d) the existence of general discourses that legitimize or delegitimize certain forms of coercion as they apply to particular subjects; and (e) the diffusion of contractual relations in society. Discourses, technologies, cultural norms, markets, and experience delimit and define the array of possibilities embodied in a given repertoire of coercion.

The last factor requires further analysis. Market forces tend to disseminate

I2. I prefer this formulation to Foucault's concept of "technologies of power". A repertoire entails the possibility of choice from among different forms and means of coercion, it need not be attached to a certain power-knowledge configuration, and it does not necessarily assume the effectiveness of coercion. See Michel Foucault, Discipline and Punish (London, 1977), and Colin Godon (ed.), Power-Knowledge (New York, 1980).

13. For a definition of "subalternity" see Ranajit Guha, Dominance without Hegemony: History and Power in Colonial India (Cambridge, MA, 1997); and John Beverley, Subalternity and Representation: Arguments in Cultural Theory (Durham, NC, 1999). 
contractual social relations, increasing the cost of coercive measures to the dominant. Hence, we need to redefine our "repertoires" in relation to these parallel forces. Close to an institution's repertoire of coercion are incentives (noncoercive means of achieving the same objectives), that can substitute a given set of coercive actions. ${ }^{\mathrm{I}}{ }^{4}$ Some of these incentives are strong enough to ultimately erode the logic of coercion, endowing institutional contexts with the logic of the market. Others instead reinforce, complement, and contribute to the persistence of coercive practices. Although the diffusion of this set of incentives proceeds through the complex interaction of cultural processes and social practices (the spread of "market culture"), institutions adopt these incentives - in the same way they adopt means of coercion in relation to their defined rules, objectives, and practices. And, usually, institutions internalize "market mechanisms" only to the extent that coercive mechanisms have failed. Institutional experience is, in this regard, crucial.

Two dimensions of the repertoires of coercion are important to our analysis: institutional variability, and the gradation and intensity of coercion. First, coercion is a heterogeneous and multidimensional force, unevenly distributed across social fields and exercised through different modalities. In a given society and period, coercion emerges in a variety of social fields or institutional sites (plantations, armies, convents, hospitals, the family), each with its own problematic and mode of contention. Important differences appear when we compare the intensity of violence exercised against different subalterns: women, slaves, peons, etc. This makes comparison between levels or degrees of coercion rather difficult, to the extent that coercion itself is fragmented into multiple vectors, each of them qualitatively different from the other. There is, to be sure, some modularity in the diffusion of coercion (a given form of violence can be applied in many fields of power); but each institutional context redefines the exercise, limits, and intensity of coercion, shortening, extending, or modifying the repertoire.

The notion of "repertoire" assumes that at least certain means of coercion are peculiar to a given institutional context and can only be effectively used within this field of power. The state, for instance, claims for itself the exercise of certain forms of violence (public execution, imprisonment, flogging), restraining the private usage of these modalities of coercion. Armies, prisons, or schools devise in turn their own specific regimes of discipline, borrowing certain basic conceptions from common predecessors (convents, for instance) but adapting their own repertoires of coercion to the peculiarity of their internal dynamic. Discipline, apparently a common endeavor, acquires quite distinct connotations and modalities in different institutional

I4. Even slavery, Fogel and Engerman have argued, operates on the basis of certain incentives: Robert Fogel and Stanley Engerman, Time on the Cross (Boston, MA, 1974). Their critics, on the other hand, deny that slaves were able to exercise choices as producers or consumers. See Paul A. David et al., Reckoning with Slavery (New York, 1976). 
settings. Hence, it is unlikely that the modes used by fathers to discipline children would be similar to those used by managers to discipline workers or those employed by wardens to discipline prison inmates. Institutions are spaces governed by certain rules (formal and informal), rules that are peculiar to the function of each institution. Consequently, their repertoires of coercion can overlap, but they will never be the same. ${ }^{\text {Is }}$

Secondly, the gradation of coercion (its intensity, modality and diffusion) depends on the intended destinatary. Culturally defined notions of strength/ weakness, civilization/barbarism, peaceful/violent nature govern the dominant's perception of the subaltern. ${ }^{16}$ Based upon these constructs, each subaltern subject appears to the dominant as more or less responsive to repression. Flogging, for instance, could be used against various subaltern subjects - slaves, women, children, soldiers, prisoners, etc. - but not with the same frequency and intensity, for society's toleration of this punishment varies according to the destinatary and the circumstances. ${ }^{17}$ The attribution of special propensities to certain groups or subjects also influences the intensity and nature of coercion. Forms of state violence designed for "Indians", such as military punitive expeditions or the kidnapping of relatives, are rarely applied to other subjects. This is due to the social construction of indigenous peoples as being outside the boundaries of law, market, and civilization, and hence unresponsive to legal sanction, moral condemnation, or economic stimuli. ${ }^{\mathrm{r}}$

Secondly, within an institutional setting the degree of arbitrariness and cruelty in the use of coercion depends upon the relative isolation of that field of power. Military institutions and prisons, to the extent that they do not become objects of criticism in the public sphere, can impose their own

15. Here I am following Douglas North's definition of an institution as a field governed by formal and informal rules. See Douglas C. North, Institutions, Institutional Change and Economic Performance (New York, 1990).

I6. This formulation contrasts with Norbert Elias's thesis of a general decline in the level of violence associated with the gradual "civilizing process". Instead, it sees the process of "civilization" as one that produces cultural difference in ways that simultaneously ameliorate violence against certain social subjects and increase violence against others. The self-control of emotions and the growing sensitivity towards others varies greatly depending on who "the other" is. For a discussion of Elias's views see Garland, Punishment and Modern Society, pp. 215-225.

I7. By toleration of punishment or violence I mean something akin to what Barrington Moore calls "moral grievance" or "sense of injustice". A given society tolerates certain forms of punishment or certain types of violence until they reach a certain threshold. Their members accept a certain "implicit social contract" until some of the terms of this contract are ostensibly violated. Barrington Moore, La injusticia: bases sociales de la obediencia y la rebelión, translated by Sara Sefchovich (Mexico City, 1989).

I8. In the same fashion, women are defined as being endowed with extra doses of passion, desire, and moral ambivalence, and consequently with less reason and foresight. Hence, the punishments and correctives designed for women tend to be significantly different from those designed for men: the seclusion of women, for example, takes place in religious institutions, while men are confined in penitentiaries. 
methods of punishment, even if they are illegal. Other social fields (such as factories or hospitals) are more transparent to society and, consequently, can come under the scrutiny of workers, social reformers, and publicists. The possibility that subalterns might voice their complaints, turning public grievances that usually remain within certain institutional domains, tends to restrict the use of certain means of coercion. ${ }^{19}$ For, except in conditions of the utmost impunity, dominant groups are affected by the moral condemnation of the community. Under certain conditions, subaltern groups could successfully challenge the legitimacy of certain forms of coercion. Subaltern resistance to corporal punishment, for instance, if framed within liberal discourse and assisted by liberal/radical reformers, can lower society's tolerance to such a form of coercion.

The concept of repertoires of coercion makes it possible to represent society as fragmented into a discrete set of social fields or institutional sites, each marked by its own combination of coercion and freedom. This procedure aims at a limited objective: to better describe the varieties of coercive situations (and the scope for the development of autonomy and freedom) across an ample range of conflictive social spaces. Operationally, the method is simple. It entails compiling for each social field (the household, the private ranch, the military, the police, the judiciary, etc.) a certain array of means of coercion and incentives available at a certain period. Similar to inventories, lists, or rankings, "repertoires" are useful because they help us to visualize the diversity of coercive situations and to establish meaningful comparisons between them. If society is fragmented into different social fields, what we need is a "map" of all the available repertoires in these various social fields.

Mapping repertoires of coercion is more than a taxonomic exercise. It helps us envision - and hence, evaluate - the general state of the conflictive relations between dominant and subaltern across a variety of social domains. They indicate the limits to the authority of those in dominant positions as well as the relative bargaining power of those in subaltern positions. Since coercion is neither homogeneous nor measurable, a simple array or list of possibilities of coercive action cannot generate unequivocal comparisons. Nevertheless, the mapping of these "repertoires" can serve as an important representational device for social historians. Only by placing together - at the same level - the different regimes of authority (their rules, limitations, and forms of contestation) can we assess the diffusion of coercion and contract in a given society.

If coercion and persuasion (incentives) were measurable and homogeneous, it would be possible to rank social fields according to their degree of

19. For the passage between hidden and open resistance see James C. Scott, Domination and the Arts of Resistance (New Haven, CT [etc.], 1990). See also, Albert O. Hirschman, Exit, Voice and Loyalty (Cambridge, MA, I970). 
coercion. ${ }^{20}$ But coercion and persuasion are neither measurable nor homogeneous. The historian can quantify coercion only in cases of obsessive bureaucratic obedience (officers of the British Navy kept records of the floggings given to the marines) or in relation to minor forms of coercion (fines for violations of factory discipline). In most cases, quantification is not an option for social historians. In addition, the qualitative diversity of the phenomenon poses an insurmountable problem of aggregation. Hence, we need to resort to means of representing power relations which make intensive use of available qualitative information.

The more interesting historical records present us with microsituations of power which we cannot easily aggregate. Judicial and military archives to touch only on the most fertile source for social history - give us only a selective sample of interactions between dominant and subaltern. From these microlevel interactions, we can infer some generalizations about the relative power of dominant groups, the claims of subaltern subjects, and the types of coercion prevalent. The representativity of recorded cases in relation to the totality of social interactions should be judged in the context of a given historical conjuncture. Only in relation to its historical context can a given microsocial interaction be considered "typical". Statistics on crime, migration, employment, and household composition can help us contextualize the main processes and forces at work. But they are no substitute for the analysis of microlevel interactions based upon cases extracted from the archives.

In general, many acts of vocal and physical resistance have found no place in the official records. And the greater the degree of domination and hegemony in a given society, the less likely dissenting voices are to appear in the archives. ${ }^{21}$ But this obstacle has not deterred social historians from analyzing the different components of what Foucault called the "disciplinary archipelago": households, factories, prisons, schools, army regiments, etc. What we need is a way to reassemble these discrete findings into a larger construct. What we need is to consider the different repertoires of coercion as interrelated possibilities within a larger compound called society.

\section{MAPPING REPERTOIRES: THE ROSAS PERIOD}

(1829-1852)

In this section, I put the concept of repertoires of coercion to work, showing the forms of violence used during the Rosas period (I829-1852) in different institutional contexts. I examine only a few important aspects of these fields

20. In such a case, a movement from a more coercive to a less coercive point would be analogous to a movement from coercion to contract, and if various social fields demonstrated the same type of movement society as a whole could be said to be experiencing a transition from coercion to contract.

2I. See Scott, Domination and the Arts of Resistance. 
of power: politics and government, the justice system, the army, the estancia or cattle ranch, and the household. I omit other institutions (such as schools and the Catholic church) and regulatory powers (justices), mainly because of the lack of reliable information about microsocial interactions. The selection made also reflects the need to place on the same plane violence unleashed by the state against different social actors (political dissidents, indigenous peoples, itinerant rural workers, and soldiers) and to contrast the options open to the different subalternities.

\section{The government (political violence)}

In possession of "extraordinary faculties" to govern, Juan Manuel de Rosas had, no doubt, the greatest means of coercion at his disposal. He could use the justices of the peace, the army, the police, or the secret society (the Mazorca) to enforce laws, persecute opponents, and "restore" order and tranquility. His administration was later remembered as a dictatorship or tyranny, because of the violence and terror he exerted over the unitarios, middle-class, literate porteños, accused of plotting with foreign governments against the Argentine Confederation. Using lists drawn up for the purpose, the government confiscated the property of the unitarios and forced them into exile in Chile, Uruguay, and elsewhere. The Mazorca, a secret society of activists supporting Governor Rosas, assassinated political opponents and carried out all sorts of acts of intimidation. ${ }^{22}$ The purpose behind all this violence, according to the federalists, was to avoid the dismembering and destruction of the republic, threatened, they claimed, by a group of "anarchists".

The civil war itself (confronting unitarios against federales) produced an inordinate level of violence. ${ }^{23}$ Due to the lack of prisons, it was common to execute prisoners on the spot: degüello, the severing of the prisoner's head using a knife, was the preferred technique. After summary proceedings, famous unitario leaders were shot, and their heads cut off and exposed on poles for several days. ${ }^{24}$ While unitarios were the prime target of political

22. Though opponents of Rosas claimed there were thousands of these assassinations, the historian Ernesto Quiroga Micheo claims the Mazorca carried out about eighty murders during the period I833-I852. The remaining political assassinations were carried out by army officers and a police chief; Ernesto Quiroga Micheo, "Los mazorqueros. Gente decente o asesinos?", Todo es Historia, 308 (March 1993), pp. 38-55.

23. Conceived as a "Holy War" against an illegitimate group of rebels, the civil war had to be carried to the end, at all costs, by all good federales. Otherwise, the federalist republic, threatened by a group of "anarchists" allied with foreign powers, could be destroyed. These powerful reasons were used to justify the violence directed against the unitarios, the forced recruitment for the army, the requisition of provisions, and confiscations, etc.

24. On 3 October I84I, six unitarios were publicly executed (shot by a firing squad) in Tucumán on the orders of General Oribe. Marco Avellaneda, accused of having assassinated Governor Alejandro Heredia, received an exemplary punishment: his head was cut off and exposed in the 
violence, other groups also felt the consequences of the civil war. Deserters were threatened with the firing squad, and peasants who resisted army requisitions of grain, cattle and horses could expect the same treatment as the enemy. ${ }^{25}$ Although much of this violence took place outside the boundaries of Buenos Aires province (the civil war was fought mostly in other provinces), the message of terror certainly reached the province's population.

No other group experienced so much government violence as the pampa and ranquel Indians. In raids intended to terrorize certain tribes or groups not allied with Governor Rosas, soldiers attacked Indian toldos, killing adult males, pillaging all the produce they found, kidnapping women and children, and burning the toldos. ${ }^{26}$ Indians taken prisoner in combat were sent to jail, to be used later as hostages, or given to their enemies (other Indian tribes allied to the government) as servants. Indian captives, mostly women and children, were circulated as a valuable commodity among officers, soldiers, and ranchers. While Indians captured in army raids were subject to the same technique of degüello as unitario prisoners, ${ }^{27}$ the public execution of indigenous peoples was rare. The shooting of IIO Indian captives (including men, women, and children) in a public square in Buenos Aires in 1835 brought widespread condemnation from the city's population. This might later have prevented the repeat of such a display of racist violence.

All this coercion had a purpose: the incorporation of Indian tribes into

public square (in a pica) for fifteen days; Adolfo Saldías, Historia de la Confederación Argentina (Buenos Aires, I968), vol. 2, pp. 253-254.

25. Being engaged in a "Holy War", many of the military leadership (unitarios and federales) argued that this punitive violence was a just retribution, the only remedy to political anarchy.

26. Prudencio Arnold, an officer who commanded various campaigns against Indian tribes during the Rosas period, wrote: "The Indian is a barbarian and a savage; but the Christian is no less [barbaric and savage] [...]. How can one not expect retaliations when our destacamentos [military expeditions] take away the products of the malón [Indian invasion], burn their toldos, kill their men and their old women, peal away pieces of their skin to make hobbles that later hang from the [Christians'] horses' necks during their festivals?"; Prudencio Arnold, Un soldado argentino (Buenos Aires, 1970), p. I03. For a comprehensive view of uncristiano relations during the postIndependence period see Martha Becchis, "Inter-Ethnic Relations during the Period of NationState Formation in Chile and Argentina: From Sovereign to Ethnic" (Ph.D., New School for Social Research, New York City, 1983); and Carlos Martínez Sarasola, Nuestros paisanos los indios (Buenos Aires, 1992).

27. Federales justified these executions in terms of the need to exterminate their political and military foes (unitarios), whom they considered "a race" of "anarchists", deserving no consideration and possessing no rights. Federalist colonel Mariano Maza wrote from Catamarca: "Again, the savage unitarios wanted to take our Restorer from us. As now it is necessary not to give away any advantages, I am ordering the execution of all the savages I had as prisoners, among them Luis Monterola, who served in Lavalle's artillery. Tiburcio Olmos had also been given 'the passport'. My friend, knife and bullets with this race! If today I had had a thousand prisoners I would have 'dispatched' the thousand." Quoted by Saldías, Historia de la Confederación, vol. 2, p. 255. The other side, the unitarios, showed no less cruelty and violence. With the assuredness of religious conviction, General Lamadrid wanted to burn in the hoguera all montoneros found in Cuyo (in I838). "We need to finish with these heads if we want tranquility to be restored"; Ibid., p. 256. 


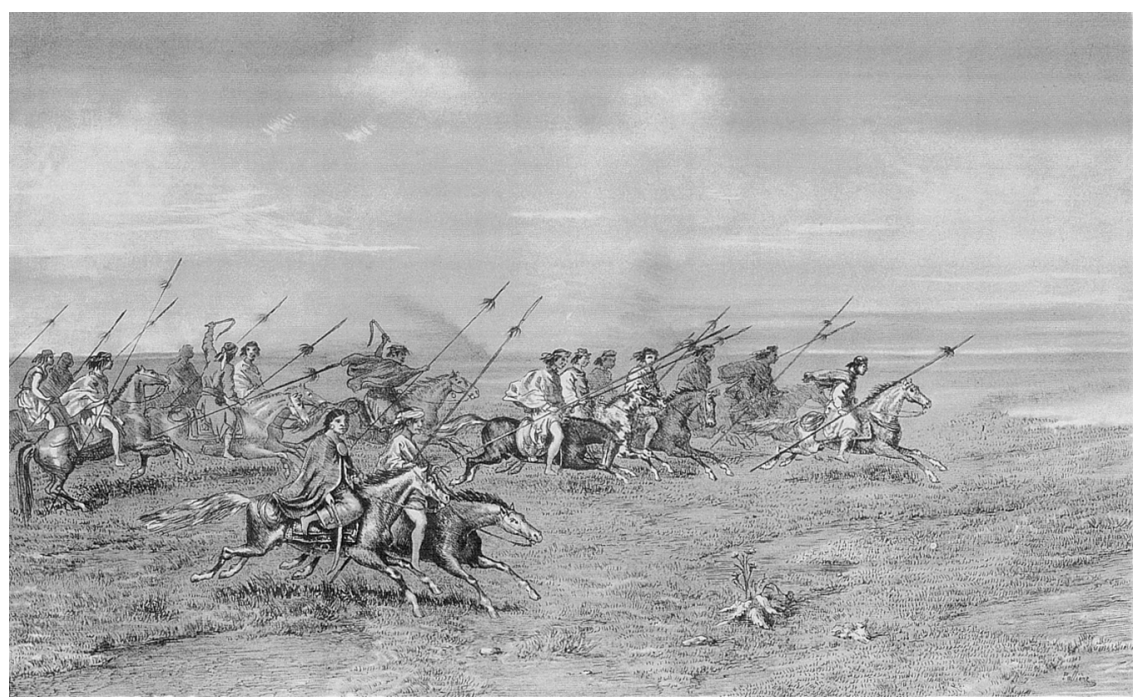

Figure 3. Leon Palliere, Invasion de Indios, (lithograph, I86os). During the Rosas period, the frequency of "malones" or Indian "invasions" became less frequent, as Rosas established a system of gifts or subsidies in kind to keep "friendly Indians" on his side. Those tribes who did not accept the conditions imposed by the provincial state, received as retribution "punitive raids" by the army in which property was destroyed, women and children were kidnapped, and adult tribesmen were killed.

From Leon Palliere, Escenas Americanas (Buenos Aires: Litografia Pelvilain, I864)

the aegis of the provincial state under conditions that ensured the cristiano laws of property. Rosas expected that independent tribes (the so-called indios del desierto) would become "allies" and "friends" and enter the state machinery as dependent and honest "children" living on state provisions. This entailed signing peace treaties, promising to stop appropriating cattle from ranches, resettling in a zone controlled by the army, and, of course, avoiding any association with the unitarios. If they did all this, they could expect periodic "gifts" (regalos), provisions with which to feed and clothe their population. This was the incentive given to indigenous peoples to enter a long process of negotiation with the provincial state. In this process, Indian negotiators were subject to additional coercion, not used with other populations: relatives of caciques and capitanejos were taken as hostages and confined in state casas de espera ("waiting houses"), where they waited years for an interview with the governor or for a peace treaty to be signed.

\section{The army (military discipline)}

This institution was the locus of various forms of coercion, most of which affected peasants, laborers, and the rural youth. To recruit new soldiers, the 
army had to combine various mechanisms: (I) the enganche, a system which enlisted men by advancing them a lump sum of money in exchange for a one- or two-year contract; (2) the contingentes, small groups of men pressganged into the army and sent by the justices of the peace on a regular basis (two to four each month); (3) the sentencing of delinquents to terms of service in the army (regularly, two to four years); (4) the commissioning into specific regiments of militiamen already registered in their districts (usually in times of war), and ( 5 ) wartime levas, indiscriminate drafts used at the beginning of a war or military campaign. In addition, (6) there were campaigns against the unitarios (the so-called restauraciones), which, due to their political and ideological importance, attracted many voluntary recruits. ${ }^{28}$ State coercion figured prominently in (2), (3), and (5), whereas economic incentives, communal pressure, and political affinities weighed heavily in (I), (4), and (6). The degree to which the army used these different mechanisms depended upon the relative efficaciousness of each of them, and this in turn depended on the degree of resistance or compliance of the rural population.

During this period, we see a reduced dependence on wartime levas ( 5 ) and an increasing reliance on the drafting of militiamen (4), and on judicial sentencing (3). Perhaps the most significant change introduced by Governor Rosas was to tie military recruitment to the criminal justice system. Regularly, peasants and laborers accused of a variety of crimes were arrested and prosecuted by local justices, and then escorted (with their hands and legs in shackles) to the army's headquarters at Santos Lugares, where the governor himself sentenced them to fixed terms of military service. ${ }^{29}$ Despite Rosas's insistence, the system of contingentes did not produce many draftees. Adult males fled when justices were trying to fill their monthly quota, and only the very young were caught. Thus, most of these draftees were twelve- to fourteen-year-olds recruited for the regiments' bands (to play horns, flutes, and drums). For special corps (Rosas's Scort Battalion for example), the army preferred hired soldiers, the enganchados. Some of them were new men recruited in the provinces, others were veterans who decided to stay on after their term of compulsory military service had ended. This method of recruitment was particularly useful at times of great danger to the Confederation (in I850-I85I for example), when willing, skillful veterans were preferred to untrained and reluctant peasants and laborers.

The rural population, with fewer social and economic resources, received the full brunt of forced military service. Youngsters without parents or protection were the easiest target for arrest. Migrants from the provinces and

28. To an extent, these were social and political rural mobilizations, destined to repair damage done by the unitarios.

29. These terms varied from one to fourteen years, the most common sentence for theft or homicide being four years. 
itinerant workers who lacked local connections were also in the mire with the recruiting authorities. Deserters and draft-dodgers were considered worse than "outsiders": their reluctance to serve the "federal cause" was a sure cause of arrest. A large proportion of draftees were white and mestizo (trigueños), blacks and mulattos representing a significant minority. ${ }^{\circ}$ Indigenous peoples, who were not considered a reliable component of the army, were less subject to forced military service. The army incorporated some Indian units, but always for operations in frontier territory and under the close supervision of a larger cristiano force.

Officers used other mechanisms to instill into recruits the rules of obedience and hierarchy. One reason prompting soldiers to desert was the use of palos (strokes made using a sword) as a means of discipline. ${ }^{3 \mathrm{I}}$ Verbal abuse and the channeling of soldiers' labor into officers' private enterprises (which usually involved the soldiers working on the officer's ranch or farm) were other forms of coercion that veterans found difficult to tolerate. It was rare, though, for officers to inflict wounds on rebellious soldiers.

In addition to coercion, the army used a whole array of incentives. Whether they joined involuntarily or out of self-interest, soldiers received a salary, a ration composed of meat, salt, and vicios (tobacco and yerba), and a uniform. Sums of money, auxilios, were given to soldiers at the beginning or end of a battle. In addition, some of the hides of the animals slaughtered for the battalion's supplies were distributed among the soldiers. ${ }^{32}$ On occasions, Rosas established special rewards of money, cattle or land for the veterans of a particular campaign (the "campaign of Córdoba", the "campaign to the desert" for example). Permits or leave bargained between soldiers and officers were part of the normal life of battalions. "Leave to work" was a peculiar concession, which allowed soldiers to go and work for wages in the private economy for one to three months, returning later to their battalions.

\section{The criminal justice system (legal coercion)}

During the Rosas era, the combination of old colonial laws and institutions with a liberal discourse on legal institutions and rights produced much

30. Over time, the separate black regiments that had fought in the revolutions for independence merged with other regiments, and by the 1840 os there was no single all-black regiment. This was part of a process of social leveling that benefited Afro-Argentines during post-Independence. See Andrews, The Afro-Argentines of Buenos Aires, pp. 6o-64.

3I. I have discussed this in "The Reasons of Deserters", a paper presented at the Program of Agrarian Studies, Yale University, February 1994.

32. I have discussed this in "El mercado de trabajo en la campaña bonaerense (I820-I860). Ocho inferencias a partir de fuentes militares”, in Marta Bonaudo and Jorge F. Sábato (eds), La problemática agraria. Nuevas aproximaciones (Buenos Aires, I993), vol. I. 
ambiguity and confusion. ${ }^{33}$ An arbitrary system of adjudication that left final sentencing power to the governor coexisted with the functioning of regular courts, observant of legal processes and terms. ${ }^{34}$ The power to punish was shared by the governor, the tribunals at Buenos Aires, and the local justices of the peace. Within such confusion of jurisdictions and legal systems, some old forms of punishment (such as the stakes, whipping, and public executions) survived.

For misdemeanors and crimes that did not merit sending the felon to Rosas, justices of the peace imposed a variety of penalties: fines, a few days of unpaid labor for the local parish, one or two days on the stakes, or a varying number of strokes. ${ }^{35}$ For more serious crimes, such as murder, desertion, theft, or vagrancy, justices substantiated the case and sent it to Rosas for a decision. Usually the governor sentenced the accused to two or more years forced service in the army. Political crimes (judged in ordinary courts) were punished severely. One memorable public event was the execution on 23 October 1837 of the Reynafé brothers and Santos Pérez, who had been charged with the assassination of General Quiroga. As was the custom, their corpses were hanged from the gallows (after they had been shot) and exposed to public view for half a day. A lottery decided which of the accomplices (also sentenced to death) would actually be shot; the rest were forced to witness the executions. ${ }^{36}$

Whereas the judges, policemen, and wardens did not economize on violence, forms of corporal punishment quite common in colonial times (such as the potro or the rueda) were less prevalent in this period. Judicial torture, in particular, seems to have disappeared. ${ }^{37}$ On the other hand, public pun-

33. Osvaldo Barreneche, "Criminal Justice and State Formation in Early Nineteenth Century Buenos Aires, Argentina” (mimeograph).

34. Supporters of the regime justified Rosas's resort to swift justice during this period of "anarchy". Rosas, said the author of "Cartas sobre la América del Sur", an article in defense of the regime published in La Gaceta Mercantil, January I844, uses less cruel punishments than European governments. The quick resolution of cases, omitting certain requirements of due process, was justified due to the "ruin of all authority and law" prior to the Rosas administration. Quoted by Jorge Myers, Orden y Virtud. El discurso republicano en el régimen rosista (Buenos Aires, 1995), pp. 232234.

35. See Ricardo D. Salvatore, "The Crimes of Poor 'Paysanos' in Mid-Nineteenth-Century Buenos Aires Province", in C. Aguirre and R. Buffington (eds), Reconstructing Criminality in Latin America (Durham, NC, 2000).

36. The public interest generated by this trial is captured by Silvia Mazzuchi and Héctor Sambuceti, "Santos Pérez: Alegato y ejecución", Todo es Historia, 308 (March 1993), pp. 26-36. A fictionalized account of the execution and the grotesque responses of the public can be found in Eduardo Gutierrez, Juan Manuel de Rosas. Los dramas del terror (Buenos Aires, 1944), pp. I80197. Though much less frequent, public executions also extended to common murderers and, occasionally, to deserters.

37. For a description of judicial torture and other forms of judicial violence during the colonial period, see Ricardo Rodríguez Molas, "Torturas, suplicios y otras violencias", Todo es Historia, 192 (May 1983), pp. 8-44. 
ishments intended to impress the governed with the actual powers of the republican authorities were on the rise. After a decade of "anarchy", the didactic function of public whippings and the stakes (and, occasionally, of public executions) was considered essential for "restoring the laws". Mainly because jails and prisons were no guarantee of confinement, shackles (grillos and barras) remained an instrument of widespread use despite their prohibition in I8I3. Two prisons served to detain temporarily all kinds of law offenders (debtors, political opponents, common delinquents, deserters). One of them, the Cárcel Pública, acting in response to the demands of masters, received domestic servants (most of them slaves) for whipping or "correction".

The criminal justice system possessed an ample repertoire of coercion (fines, whipping, detention, forced labor, the stakes, etc.). A double purpose oriented its efforts: to preserve the "tranquility" of the countryside, and to produce enough recruits for the federalist army. A local justice oriented towards the resolution of neighbors' conflicts and the preservation of public order coexisted with a centralized justice that identified and arrested deserters, draft-dodgers, and reluctant federales. ${ }^{38}$ This complex system of justice produced different levels of violence. Local, "moralizing" justice, dealing with "neighbors" (vecinos) endowed with voting rights, was in general less coercive than centralized, "recruiting" justice, which repressed "transients" (transeuntes) devoid of these rights. Also, it is reasonable to argue that local justice was more negotiable, offering arrestees greater opportunity to have their sentences modified.

\section{The estancia (private justice?)}

Unlike the government or the army, the estancia had a limited repertoire of coercion. Its land was open-ended (there were no fences until the I850s), cattle herds roamed freely, sometimes mixing with those of neighbors, and labor contracts were informal, mostly oral. A few large estancias - such as those of Rosas and the Anchorenas - possessed slaves complementing the work of wage peons. ${ }^{39}$ On them, a reduced personnel (an administrator and a few foremen) supervised a widely dispersed workforce, established in puestos. The majority

38. I have dealt with this issue in "El Imperio de la Ley: Delito, estado y sociedad en la era rosista", Delito y Sociedad. Revista de Ciencias sociales, 3:4-5 (1993-1994), pp. 93-II8. For a description of the functions of justices of the peace see Benito Díaz, Juzgados de paz de campaña de la provincia de Buenos Aires (I82I-I854) (La Plata, 1959). In addition, local justices and policemen had to cooperate with the politics of the Federation, identifying and arresting political opponents.

39. This was not new to the Rosas period. In colonial times, large ranchers gave special responsibilities to slaves, appointing them foremen over mestizo peons. For an account of the occupational mobility of black peons, see Carlos A. Mayo, "De esclavo a empresario", Todo es Historia, 335 (June 1995), pp. 26-36. For the functioning of a large estancia complex, that of the Anchorenas, see Jonathan C. Brown, A Socioeconomic History of Argentina, 1776-I860 (Cambridge, 1979), ch. 8. 
of ranchers, however, owned small herds (fewer than I,ooo head) and possessed no slaves..$^{\circ}$ They had to rely on peons, hired on a temporary basis, with almost no restriction on their mobility. ${ }^{41}$ Labor turnover was so high on Rosas's ranches that by the end of each quarter each estancia had lost between fifteen and forty-eight per cent of its entire workforce. ${ }^{42}$

Under these conditions, economic incentives were more effective than coercive measures in securing the cowhands and shepherds needed. Operating in a context of recurrent civil wars, which exacerbated existing shortages of laborers, ranchers had to entice highly mobile workers to stay on the estate. Bringing peons from other districts (including the northern provinces), offering higher wages or promising additional benefits to newcomers (such as piece-rates for extraordinary tasks, or the possibility of bringing their families onto the ranch) were some of the means open to ranchers to augment their labor force. ${ }^{43}$ Shepherds received a share of the new flock. Credit extended through the ranch's pulpería was an additional incentive. Despite these benefits, ranchers found it difficult to establish a stable workforce, being forced to rely on day laborers for seasonal tasks such as harvesting grain, branding cattle, and shearing sheep. ${ }^{44}$

Some authors have seen in this period the emergence of a peculiar form of dependence tying peons to the ranchers. Forced recruitment, these authors claim, produced such fear among the poor in the countryside that they took jobs on the estancia simply to be safe from police and military persecution. ${ }^{45}$ Others believe that peons were forced to remain on the estate

40. Recent studies have seriously questioned the conventional wisdom of the great power of estancieros. Their influence on government policies and their concentration of economic resources were less important than previously thought. And, until the late nineteenth century, they failed to act with either the cohesion or purpose that characterizes a social class. See Carlos A. Mayo, "Landed but not Powerful: The Colonial Estancieros of Buenos Aires (1750-1810)", Hispanic American Historical Review, 7I (199I), pp. 76I-779; Salvatore, "Autocratic State and Labor Control", pp. 25I-278; and Tulio Halperín Donghi, "Clase terrateniente y poder político en Buenos Aires (I820-1930)”, Cuadernos de Historia Regional, 5:15 (1992), pp. II-45. For an overview of the literature see Raúl Fradkin, "La historia agraria y los estudios de establecimientos productivos en Hispanoamérica colonial: una mirada desde el Río de la Plata”, in R.O. Fradkin (ed.), La Historia agraria del Río de la Plata Colonial. Los establecimientos productivos (Buenos Aires, 1993), vol. I, pp. 7-44.

4I. Assured that the police would not bother to arrest them for breach of contract, peons moved from one district to another in search of family, entertainment, or better opportunities. Many were simply escaping military conscription.

42. Slatta, Gauchos and the Vanishing Frontier, pp. 32-33, especially Table I.

43. Reluctantly, ranchers accepted the logic of the market. See Salvatore, "Autocratic State and Labor Control”, esp. pp. 262-267.

44. See Jonathan C. Brown, "Revival of the Rural Economy and Society in Buenos Aires", in Mark D. Szuchman and Jonathan C. Brown (eds), Revolution and Restoration: The Rearrangement of Power in Argentina, 1776-I860 (Lincoln, NB, 1994), esp. pp. 255-264.

45. This I call the "fear-protection thesis". See, for example, Lynch, Argentine Dictator; Rodríguez Molas, Historia social del gaucho; Andrés Carretero, La propiedad de la tierra en la época de Rosas (Buenos Aires, 1972); and Gastón Gori, Vagos y mal entretenidos (Santa Fé, NM, I95I). 


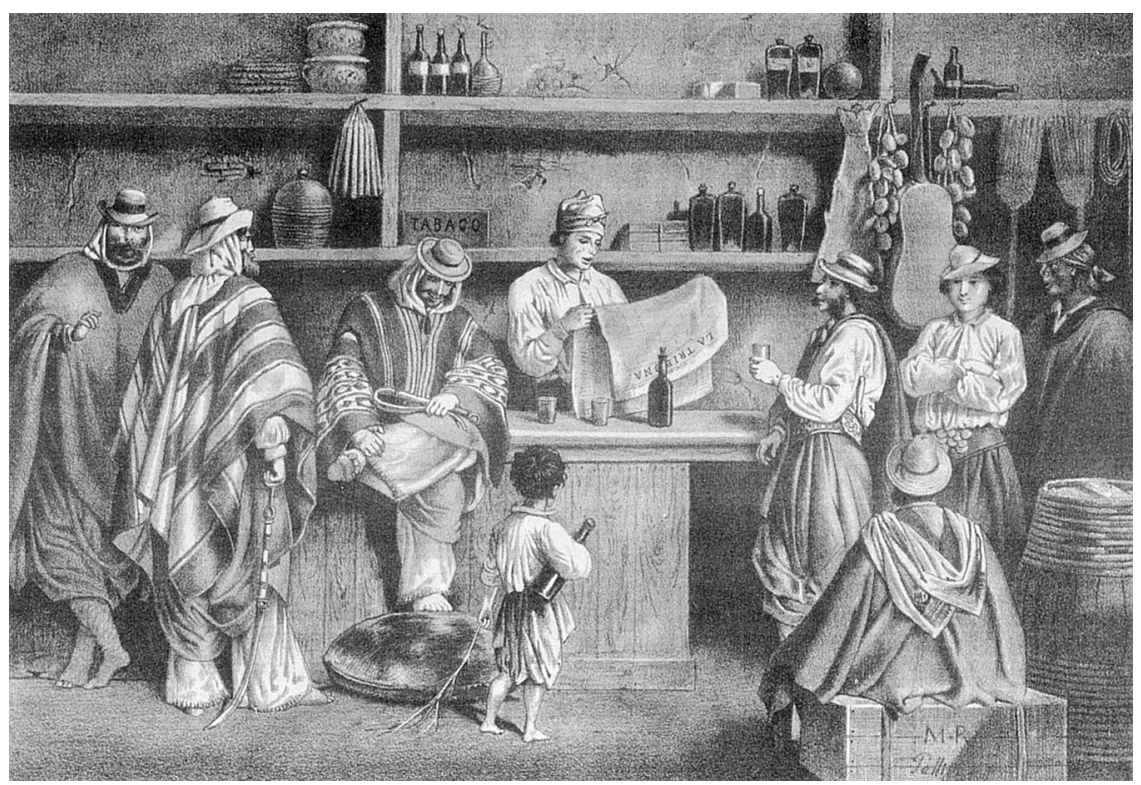

Figure 4. Leon Palliere, La Pulpería, (lithograph, I86os). In rural taverns, or "pulperías", itinerant workers, peasants, and other neighbors gathered to listen to the news about the political affairs of the nation, read aloud by the tavern-keeper or by any other literate resident. During the Rosas period, justices of the peace were instructed to perform this pedagogical exercise on a regular basis. From Leon Palliere, Escenas Americanas (Buenos Aires: Litografia Pelvilain, 1864)

due to the heavy debts they built up with the ranchers' pulpería. However, none of these forms of dependence was sustainable or effective. In a political milieu in which protecting deserters was considered treason, ranchers were not eager to provide a safe haven for their peons. Those who did so found that justices of the peace and military commanders had powers to set foot on their property and arrest their peons, and that their promises of "protection" to fugitives of justice were difficult to realize. Estancia accounts show that debt did not prevent peons from leaving the ranch. And justices, who did not consider it their obligation to persecute debtors, rarely arrested peons who abandoned the ranch before their term. ${ }^{46}$

Does this does mean that the estancia became an environment free from coercion? Not at all. Some degree of coercion was exerted against the few slaves remaining on medium and large ranches. While slaves went to the countryside with the promise of a better life (working as foremen) or with an agreement for their future freedom (some discounting from their wages the installments for the purchase of their freedom), their inducement to

46. Some of them were later arrested in other districts for not carrying the papeleta de conchavo (work certificate), but such arrests were relatively rare. 
produce was not always economic. Ranchers threatened slaves with unwanted sales to other destinations, or with the dispersal of their families. ${ }^{47}$ In relation to free wage laborers, contemporary accounts present cases of capataces (foremen) who used corporal punishment, insulting language, and death threats to discipline their workers. ${ }^{48}$ But the effectiveness of these practices must have been very limited if workers could leave the ranch the day after they were insulted or flogged. ${ }^{49}$ There were also cases of temporary coercion of adult laborers, most of them involving ranchers who had some military or judicial authority. Other forms of coercion that existed have been overlooked by historians: those suffered by orphans assigned to the rancher in crianza, and Indian women captured in army raids and later distributed among "good families". It is in relation to these rather defenseless subjects that, occasionally, some complaints about physical abuse and bad treatment appear in judicial papers.

By and large, however, the estancias of the Rosas period had become a space for negotiation rather than coercion..$^{50}$ The ranchers' limited ability to exercise coercion resulted from an experience of repeated failures in attempting to coerce labor. In the case of Rosas's ranches, these attempts involved Indian servile labor, indentured servants brought from Spain, and slaves. ${ }^{\text {II }}$ Purchasing slaves turned out to be a dead-end solution, as the closing of slave traffic and the gradual emancipation laws reduced the numbers of slaves and raised their prices. Libertos (freedmen) were perhaps more willing to take jobs, but their wages were no lower than those of other workers. The attempt to entice whole Indian tribes to work on Rosas's ranches ended in a fiasco: caciques received gifts from Rosas for months on end, but did no work in return. ${ }^{52}$ Taking Rosas's invitation literally, they

47. See M. Goldberg and S. Mallo, "La población africana en Buenos Aires y su campaña. Formas de vida y subsistencia (1750-1850)", Temas de Africa y Asia, 2 (1993), pp. 64-65.

48. We know that on late-colonial estancias slaves were locked up at night; no such practice was found in the Rosas period, mainly because good black cowboys were so scarce and useful that they were treated as free men. See Salvatore and Brown, "Trade and Proletarianization in Late Colonial Banda Oriental". Some inventories of ranches show the existence of grillos (shackles), which were most probably used to retain the few remaining slaves.

49. It is known that Rosas tried to impose a rigid disciplinary code (workers had to deliver their weapons to the foremen, had to pay fines for not carrying lassoos and bolas to work, and received floggings for minor violations) on the ranches he managed before being governor (c. I82O-I828). A traditional account of this version can be found in Manuel Gálvez, Vida de Don Juan Manuel de Rosas, in Biografias Completas (Buenos Aires, 1962), vol. 2, esp. pp. 43-45. John Lynch repeats this version to the letter; see Lynch, Argentine Dictator, pp. II4, I22, I24.

50. The estancia's limited power to coerce laborers was based in part on its separation from political power. Ranches competed with the state for scarce resources (labor, cattle, horses), and could not ensure the state a sound financial base (most state revenue came from import and export duties).

5I. Salvatore, "Modes of Labor Control in Cattle-Ranching Economies".

52. In I 828 Rosas told rancher Anchorena that a "multitude" of Indians were living on the ranch. He failed to mention how many of them were actually doing work for the ranch. Rosas to J.J. Anchorena, Cerrillos, I3 June I828, AGN VII-I6-4-7, no. I364. 
helped themselves to all the cattle and mares they needed, causing enormous losses to the estancia. ${ }^{33}$ Rosas's luck with indentured Spanish youths was no better. After a while the youngsters, who owed Rosas their passage, stopped paying back their debts and insisted on being reassigned elsewhere. Some of them joined the army, some the administration, and others simply left the ranch. ${ }^{54}$

If the governor, possessing vast tracts of land and special information about the movements and past of subaltern subjects, was unable to create a viable coerced labor force, other ranchers with less property, clout, and information were probably even less able to do so. ${ }^{55}$ Hence, ranchers had to depend on the inexorable logic of the market. The most effective method for attracting peons was paying by the day. This was enormously expensive to the ranch, but it was the only way to secure laborers for tasks (such as branding and round-ups) that demanded large numbers of peons. In addition, ranchers could offer workers some access to land, a share of the yearlings, a set of new clothes, or other benefits. Some of these benefits, however, turned peons into agregados, individuals residing with their families within the boundaries of ranch property. Admitted under the vague promise of "helping" the ranch when needed, the multiplication of agregados was less than a blessing for the ranch economy. Indeed, Rosas's Instrucciones a los Mayordomos recommended not admitting agregados because of the great costs in terms of cattle and resources they implied to the ranches.

Workers' families constituted another point of negotiation and contention. One of the changes introduced in this period was the selective admission of women on the estancia. Ranchers began to reject peons who came with their families, mainly because the presence of young women created unnecessary tensions among male workers. ${ }^{56}$ Only the foremen and the puesteros (peons in charge of a cattle herd) were given the privilege of raising a family on ranch property. This change in ranchers' policies coincided with the outbreak of wool fever (1840-1860). As sheep-raising could be organized delegating the recruitment of peons into sharecroppers

53. In the end, of the thousands of "braves" who resided for months on Rosas's lands, less than thirty took jobs as ranch hands. Some of them, with new Christian names and new clothes, remained with Rosas for years.

54. In order to retain the rest, Rosas had to design a wage system that paid extra for each year of seniority, raising labor costs for the estancia.

55. Elsewhere, I have discussed the difficulties ranchers faced when confronted with the task of reconstructing labor relations in the post-Independence period. In Corrientes, the Robertsons used a charismatic and violent capataz, Mr Campbell, to keep peons in check, while their credit worked miracles in buying up the local production of hides, tallow, and hair. The experience lasted only a couple of years and was later abandoned. Ricardo D. Salvatore, "The Breakdown of Social Discipline in the Banda Oriental and the Littoral, I790-1820", in Szuchman and Brown, Revolution and Restoration, pp. 74-IO2.

56. John Brabazon, Andanzas de un irlandés en el campo porteño (I845-1864) (Buenos Aires, I98I), pp. $176-177$. 
and tenants - usually Basque and Irish - ranchers were able to be more discriminating in relation to the creole workers employed in cattle operations. $^{57}$

\section{The household (power over family and servants)}

The control of masters over domestic servants, already diminished in the late colonial period, became highly contested during the Rosas period. Scholars have noted the peculiar nature of slavery in late-colonial Buenos Aires, where men and women in bondage looked for jobs in the open market, negotiated wages, and worked outside the master's home, paying to their masters a portion of their earnings. ${ }^{58}$ Their masters were men and women of modest means, highly dependent on the wages generated by their slaves. ${ }^{59}$ In most workplaces (brick kilns, bakeries, stockyards, construction sites) slaves and free men worked and slept together. And, more importantly, wage-earning slaves were naturally in the business of purchasing, little by little, their freedom.

The almost contractual nature of domestic slavery limited the possibilities of coercion open to masters. ${ }^{60}$ Hired-out slaves were almost free from surveillance by owners; they had to adjust only to the provisions of their craft and to the desires of their bosses. Domestic slaves living in their masters' houses were subject to closer supervision and coercion. ${ }^{6 \mathrm{~T}}$ Though whipping was restricted by law (slaves were able to demand their sale if masters flogged them), masters could, if they wished, put their servants to humiliating or unwanted tasks, lock them up at night, and reduce their food and clothing provisions. Few of them actually did, preferring instead the use of incentives in order to secure good service and deference. They hired the slaves out, sent them to a farm or ranch, allowed them to keep their savings, promised them some inheritance or reward after their master's death, or, more commonly, made arrangements for the future manumission of the slave.

During post-Independence, masters' repertoires of coercion experienced further reductions. The I8I3 Assembly declared the freedom of slaves' new-

57. The wool economy, on the other hand, brought more women into "productive" activities. Ranchers who refused to allow women to do such tasks as shearing, milking, and wool cleaning ran the risk of jeopardizing production.

58. See Johnson, "Competition of Slave and Free Labor", and Eduardo Saguier, "La naturaleza estipendiaria de la esclavitud urbana colonial. El caso del Río de la Plata en el siglo XVIII", Revista Paraguaya de Sociología, 26:74 (1989), pp. 45-54.

59. The law obliged slaves to provide a daily payment to their masters. Johnson, "Competition of Slave and Free Labor", p. 4I6.

6o. "For thousands of slaves in late colonial Buenos Aires, slavery meant weekly or, less commonly, monthly, cash payments paid to the owners." Ibid., p. $4 \mathrm{I} 8$.

6I. At the beginning of the eighteenth century, nearly eighty per cent of all slaves in the city of Buenos Aires were domestic servants, the remaining twenty per cent worked in artisan shops or on nearby farms. Ibid., p. 4II. 
born children and established a transitional regime whereby these children (libertos) were put under the custody of masters. ${ }^{62}$ Contemporaneously, rescates (purchases of slaves) made by the state for military purposes gave adult slaves an opportunity to escape bondage. They were to serve five years in the army, after which they would be free. ${ }^{63}$ In I83I, a mandatory registration of libertos extended state protection to the definite freedom of these sons and daughters of slaves. With an increasing number of manumissions (by purchase or by reward) and relatively few additional imports (most of them illegal), the numbers of slaves declined. ${ }^{64}$ True, some legislative measures prolonged the demise of slavery, ${ }^{65}$ but the importance and viability of slavery had declined significantly by the I840s.

Particularly in the city, it became increasingly difficult to retain slaves, attracted by the freer social environment of the countryside. ${ }^{66}$ Those slaves who were in a position to negotiate their place of residence asked to be relocated to the countryside. Those who found themselves mistreated were able to force their sale in court. More commonly, slaves (male and female) escaped to the southern frontier where, with a different identity, they could make a new start. ${ }^{67}$ The wars of independence, with their rescates and acts of confiscation, encouraged slaves to make demands on masters. In order to

62. At age twenty (males) or sixteen (females), these children were to gain their freedom. Meanwhile they would provide services to their masters in exchange for education and food, and after reaching the age of fifteen (males) or fourteen (females) they would be paid a wage by their masters.

63. Other slaves were simply confiscated from Spanish masters and transferred to the army. Marta Goldberg and Laura Jany, "Algunos problemas referentes a la situación del esclavo en el Río de la Plata", in Cuarto Congreso Internacional de Historia de América (Buenos Aires, 1968), vol. 6, pp. 6I-75.

64. If the rates of manumission were the same as in the late colonial period, the number of slaves remaining by 1853 (the year the constitution abolished slavery) must have been very few. The process had started in the late colonial period, when I.5 per cent of the total slave population were manumitted each year. Lyman L. Johnson, "Manumission in Colonial Buenos Aires, I776-1810", Hispanic American Historical Review, 59 (1979), pp. 258-279. The total population of blacks and mulattos in Buenos Aires city increased only slightly from I8Io to I822 and remained stationary from I822 to 1836 . This stagnation might reflect the transfers of blacks and mulattos from city to countryside, which ran parallel to the process of gradual emancipation. See Marta Goldberg, "La población negra y mulata de la ciudad de Buenos Aires, I8IO-I840", Desarrollo Económico, I6:6I (April-June 1976), p. 88.

65. Owners of libertos managed to extend their "patronage" over young slaves and, despite the prohibition of the slave trade, slaves caught from foreign vessels found their way on to the local slave market. See Liliana Crespi, "Negros apresados en operaciones de corso durante la guerra con el Brasil (I825-1828)", Temas de Africa y Asia, 2 (1993), pp. I09-I24.

66. In the country, slaves could pass for free men, and colored men could "whiten" themselves. Once they had acquired property and social connections, it was difficult to subject them again to bondage. See Goldberg, "La población negra y mulata".

67. The proportion of mulattos was greater in the areas of older colonization, while the proportion of blacks was larger in areas of recent colonization. This is interpreted by Goldberg as clear evidence that "whitening" was a strategy for gaining freedom among slaves transported to the countryside. 
retain their servants, many masters issued "promises of freedom", which transformed labor relations during the transition period. ${ }^{68}$

During the Rosas period, old master-slave relations developed a new contractual basis. Many slave servants purchased their freedom with savings obtained from work or theft. Lacking other employment opportunities, they remained with their existing masters as wage earners. ${ }^{69}$ But, as they tried to behave as free wage earners, servants faced opposition from household heads. At the core of these conflicts were the new conditions in wage contracts. Mistresses expected female servants to perform the same duties and to be as deferential as under slavery; servants instead wanted the respect deserved by free men and women. Thus, the salarization of labor relations brought about increasing tensions within the household - tensions that revolved around questions of petty theft, leave, and the quantity and quality of work. ${ }^{70}$

Still, masters were able to send their rebellious servants to "be corrected" in the Cabildo prison: one month in prison and a few whippings (azotes) helped to restore the slave's deferential attitude. ${ }^{71}$ But within the household, the imposition of work had become highly contested. In this context, masters' threats of corporal punishment, household confinement and sale carried less of a menacing tone: they had become unproductive and unpractical.

The same could be said about gender relations within the household. The authority of male household heads over female relatives, laboriously crafted during the colonial period, ${ }^{72}$ began to show important cracks in the post-Independence period. Men's self-appointed "right to correct" women,

68. Some slaves went to court seeking the fulfillment of "promises of freedom" made by their masters. See Silvia Mallo, "La libertad en el discurso del Estado, de amos y esclavos, I780-I830", Revista de Historia de América, II2 (I99I), pp. I2I-I46.

69. The transition towards paid labor was the most important change regarding female servants. 70. As a result of these increased tensions, many morenas and pardas were sent to jail "for correction" on charges of theft, insolence, or insulting behavior. Theft seems to have been the single most common cause of arrest of female servants. Driven by the urge to "dress up" in order to gain respectability, or simply in need of money to help family and lovers, many female servants felt entitled to appropriate their masters' money or clothes.

7I. In the countryside, female captives freed from the Indian toldos were sometimes reduced to servitude under the custom of crianza. In practice, these servants were treated worse than slaves, being subject to punishments and abuse. Juan Méndez Avellaneda, "Entonces la Mujer", Todo es Historia, 286 (April 199I), pp. 50-5I.

72. During the colonial period, the household was the central locus of patriarchal authority. Here the man of the household dominated his family and servants, most of them chattel slaves. $\mathrm{He}$ used both legal and extralegal coercion to maintain the deference and obedience of wife, children and servants. In relation to slaves, the household head had various means of coercion he could use: confinement, corporal punishment, food privation, and sale (to separate the slave from his or her family). In relation to female relatives (wife and daughters), similar mechanisms were available: corporal punishment, clothing and food privation, and house confinement. In extreme cases, he could use convent cloisters to discipline a rebellious daughter or an unfaithful wife. 
in particular, became a contested issue as many women took to court cases of abuse by their male partners, finding to their surprise that judges were sympathetic to their demands. ${ }^{73}$ Ricardo Cicerchia has shown how poor women went to the courts to redress the abuses of men, demanding economic support or accusing men of ill-treatment. In most of these cases, the plaintiffs (women) won. ${ }^{74}$ Male abuse of women was particularly violent and cruel in this period - knife wounds often accompanied rape attempts but women's courage in reporting these cases and fighting in the courts for the conviction of offenders produced unexpected results. The case of a battered mulata who managed to get her husband banished (desterrado) or the case of a poor white women who, with the help of female friends, got a male assailant sentenced to military service are indicative of the opportunities open to women of all classes in the courts. ${ }^{75}$

By various means, women contested patriarchal authority. Wives asked the ecclesiastical courts to grant separations, challenged the privilege of husbands to administer inherited wealth, and demanded from them the provision of food and clothes when husbands failed to meet their responsibilities. Women from the lower classes, who were less able to pay the expenses of a trial, opted for a more expedient solution to their marital difficulties: escape. They ran away to the southern frontier, where the vengeance of husbands and fathers could not reach them. Some women responded to male violence in kind; cases of women attacking their male partners with knives and guns were not uncommon. Devoid of the support of church and state, male heads of households saw their repertoires for coercing women greatly reduced.

\section{THE ATTRACTION OF MARKETS}

From late colonial times to the end of the nineteenth century, Buenos Aires province suffered from a chronic shortage of laborers. ${ }^{76}$ This feature of the economy had a pervasive influence on the formation of coercive institutions. Scarcity in the labor market conditioned the authorities to exercise less violence than they would have in a market with an excess labor supply. The discourse on individual rights and equality propagated during the wars of independence, combined with the experience of high occupational, spatial,

73. With the help of an escribiente, they narrated in detail the violence of their husbands, hoping to impress male judges - claims of sword beatings during pregnancy certainly made an impression. 74. Ricardo Cicerchia, "Familia: la historia de una idea. Los desórdenes domésticos de la plebe urbana porteña, I776-1850", in Catalina Wainerman (ed.), Vivir en familia (Buenos Aires, 1994), pp. 49-72.

75. Elite judges, horrified by the violence perpetrated against women, often sided with the victim. 76. Lyman L. Johnson finds this situation characteristic of the late eighteenth century, when Bourbon reforms accelerated the pace of economic growth and the growth in labor demand exceeded the growth in labor supply. See Johnson, "Competition of Slave and Free Labor". 
and racial mobility, engendered a diffuse form of contractualism whose influences could be traced in different institutional contexts, public and private, disciplinary or market-oriented. Accustomed to negotiate with their superiors, subaltern agents usually bargained their way out of coercive situations. A less egalitarian, more deferential society would have produced fewer opportunities for this type of negotiation.

In various ways, the attraction of markets influenced the effectiveness and diffusion of coercive power in Buenos Aires province. The porosity of institutions to the incentives generated in the labor market was already visible in the post-Independence period, and it only became more widespread with the consolidation of a more intrusive and vigilant state during the Rosas dictatorship. Paradoxically, the intensification of political violence against unitarios and of racial violence against indios enemigos was accompanied by a diffusion of contractual relations in various fields of social interaction. In military garrisons and households with servants the power of officers and masters to impose obedience and respect found limits in the allure of labor markets. The high labor mobility and the bargaining practices of the "private economy" spilled over into the terrain of public policy, state institutions, and even into the domestic sphere.

Several factors engendered this peculiar configuration of coercion and incentives in post-Independence Buenos Aires province. Among them was the existence of a plebian culture saturated with ideas of personal autonomy and civil rights, activated by the struggle for independence and the ensuing civil wars. Also important was the configuration of politics and state formation during the turbulent post-Independence period. The authority of the state (and the legitimacy of Rosas's mandate to "restore order") depended crucially upon a basic unwritten "contract" between the peasantry and the government for the provision of military services and other contributions to the fatherland. Abuses of this reciprocity pact eroded the basis of obedience and patriotic cooperation. To the degree that they shaped individual conduct and self-perceptions, market interactions contributed to create a culture of negotiation and defiance among subalterns.

A society characterized by a chronic shortage of labor (as Buenos Aires was during the first fifty years after Independence) tends to generate recurrent attempts to restrain the mobility of workers. At the same time, this society produces a constant attraction for coerced workers to improve their situation, entering contractual wage relationships. The attraction of markets tends to erode the effectiveness of a given coercive system, as people under restraint always include the powerful appeal of high wages in their calculation of the risks and benefits of escaping. The power of markets was pervasive in Buenos Aires province, affecting coercive institutions such as slavery, the military, and the police. Labor scarcity, and the widespread contractualism that this created among the subaltern classes, also affected 
power relations within households and courts. ${ }^{77} \mathrm{~A}$ few examples of situations of coercion in the 1840 and 1850 os will help us to make this point clear.

In I850, Manuel Flores, a migrant from Córdoba, was arrested in Mar Chiquita for lacking conscription papers. After arriving from his province, Flores had lived for six years in Dolores without problems. Then, he enrolled in the 5th Infantry Regiment for two years, after which he deserted and went to Ajó. There, he worked for a while as assistant to the justice of the peace. His desertion passed unnoticed until he moved to Mar Chiquita, where a zealous JP, Juan Manuel Saavedra, suspected him and ordered his arrest. He was in shackles for two months until the JP made him the following proposition: if he agreed to work as a peon on Saavedra's ranch, he could avoid being sent to Rosas's headquarters in Santos Lugares. Having no better alternative, Flores accepted the proposition: he was to work as a bronco-breaker, receiving $\$ \mathrm{I} 2 \mathrm{O}$ a month, a wage higher than that of a regular peon. Flores did not stay long in this job. He soon abandoned the ranch, taking Saavedra's son along as a partner in his adventures. ${ }^{78}$

This case shows the nature and limitations of coercion in Buenos Aires province. Only persons endowed with state authority (such as justices of the peace) were able to restrict the movements of itinerant peons, especially if they were deserters. This power was used mainly to enforce a labor contract. Flores was coerced into this "contract", but not necessarily cheated he was paid a competitive wage for his labor. And, despite the justice's authority, Flores was able to terminate the "contract" earlier than expected and run away. Because labor was scarce on the pampas and the rural police ineffective, the judicial authorities were unable to force people to work for a prolonged period of time. Ranchers not endowed with state authority had fewer opportunities than Saavedra to get skilled peons. Their representatives (mayordomos and capataces) did offer temporary "protection" to fugitives from justice in exchange for labor (paid labor), but this type of contract was rarely enforceable. Sooner or later, the peon had to travel to another district - driving cattle, tending oxcarts with provisions, etc. - where they risked being apprehended by the police. ${ }^{79}$

77. Limitations of space prevent us from discussing these other social fields. For domestic female servants the transition from slavery to paid labor meant not only an expansion in their freedom of movement, but also greater contention within the household regarding questions of working hours, rest, and personal treatment.

78. Flores was later rearrested, for Saavedra sent another of his sons in pursuit. "Manuel Flores (or Manuel González), filiación”, Ranchos, 30 November I850, AGN X 29-II-4.

79. This was the case with Andrés Illescay, an ex-slave who had voluntarily joined the New Regiment of Blandengues at Bahía Blanca in 1833 . Receiving a sizeable monetary advance (\$1oo for each enganche), Illescay renewed his commitment to the regiment every year. In October I843, while fighting in a campaign near Azul (in the south of the province), he deserted his regiment and moved to Juan Fernández's ranch in search of refuge. In spite of his condition, Fernández's mayordomo hired him. He was to drive cattle from the ranch to a meat-salting plant (saladero) near Bahía Blanca. He worked in this job for a total of ten months. One day, being sent to 
A long court dispute between Thomas Carr, an English mason, and the justice of the peace of Lobos also shows the limits of state authority. In I850 Carr had moved from Dolores to Lobos in search of better employment opportunities. Aware that the local justice of the peace was in need of a mason, he went to see him and offered him his services. In order to pay as little as possible for the mason's work, the justice had Carr arrested on false charges and offered him his freedom in exchange for a work contract at \$IO a day. After eight days in shackles, the English mason was ready to accept the justice's proposal. In twenty-one days Carr built a drinking basin (jaguel) and a threshing place (pisadero) for the justice's farm. After the work was finished, the mason discovered that no pay was forthcoming. As a result, when he was ordered to build brick walls for the regiment he refused. The justice then punished him with an additional eight days in shackles. Still refusing to work, Carr was dispatched to the city (on charges of traveling without a passport) to wait for Rosas's verdict. Before the mason's departure, the justice (probably afraid of what the governor might say), paid Carr \$I45 for part of his services. After so much display of arbitrary power, the justice ended up acknowledging his debt to the English mason. ${ }^{80}$

What can we make of this proximity between the exercise of coercion and market forces? Obviously, the justice's power to coerce was sufficient to bend a worker's decision about where or under which conditions to work. But in the end, wages had to be paid; even prisoners could refuse to work for free. In both cases a coercive situation rapidly turned into a contract, but the contract obtained through coercion was untenable. For workers - even those with few social connections in the province, such as interior migrants and immigrants - could escape their temporary confinement and find work elsewhere and earn a competitive wage. Employers were ready to take laborers by the day without asking too many questions. Moreover, the fugitive could denounce the justice's illegal offer, compromising the latter's situation and career. In the next partido (district) there was always an authority ready to gain from the knowledge that a certain federalist functionary had violated the law.

Within the army barracks, we find a different type of coercive situation, regulated by other institutional rules and values. To instill discipline into unwilling soldiers, officers often resorted to corporal punishment. But even within this harsh system of discipline, officers had to consider the general mobility and fluidity of subaltern life and moderate their use of the lash. Martín Garay was a militiaman enrolled in the Second Squadron of Lancers at Chascomús. He had served for many years in the federal armies and, when the civil war had subsided, he settled in Chascomús and enlisted in not extend very far. "Andrés Illescay, filiación", Bahía Blanca, 6 August I844, AGN X 26-5-3.

80. "Thomas Carr, filiación", Lobos, 4 December I850, AGN X 43-7-7. 
the local militia. In June I846 his commander sentenced him to 300 strokes (floggings) for missing two military formations (listas). Unwilling to suffer this punishment, Garay escaped from jail and ran away. Though by doing this he risked the death penalty, the militiaman could not tolerate the idea of being flogged in public. He was later arrested in Las Flores. ${ }^{8 \mathrm{r}}$

A society in transition towards a market culture is one in which tolerance towards corporal punishment is low, particularly if the lower classes had been participants in a collective and egalitarian struggle to liberate the nation from foreign occupation. The wars of independence empowered subalterns in ways that we are only recently beginning to comprehend. Corporal punishment, a treatment usually associated with slavery, carried such a stigma in post-Independence Buenos Aires that it was commonly acknowledged that a person subject to such punishment would escape as soon as he could. In many cases, the military authorities could safely assume that the offended soldier or militiaman would, sooner or later, take revenge on the superior who ordered such punishment. As hundreds of testimonies from exdeserters make clear, whipping was a moral offense important enough to justify the risk of deserting the ranks. But again, it was the labor market that facilitated soldiers' escape: the fact that exdeserters could sell their labor in a casual and noncommitted way helped them take that decision.

Another court case reveals that, even in areas such as gender relations, coercion was less productive than expected. The case of Juan Carpintero, an upper-class porteño who raped a lower-class married woman and pretended later that he had paid for her sexual services, projects us into the domestic terrain, an environment dominated by gender tensions over the control of women's labor and sexuality. This was an unusual case in which the victim denounced the assailant, turning a private, violent relationship into a judicial, public matter. The coercion in this case did not turn into a contract, for the victim did not accept this "contract". It is suggestive, though, that the assailant used the contract metaphor to get away with his crime. He did not. In spite of his "class" and his arguments, Carpintero had to spend a long period in prison. His lawyer was unable to persuade the court of his innocence. ${ }^{82}$ Judges simply did not buy the argument that the woman was a whore seeking money from an honorable member of the elite. Cuts in Carpintero's hands (made by the victim's knife) and a prior record of assault (Carpintero had raped a girl near Merlo) convinced the judges that this was a clear-cut case of rape. ${ }^{8_{3}}$ Here, the limit to coercion came not from the market but from peer condemnation. Shared notions about the

8I. "Martín Garay, filiación", Las Flores, I June I846, AGN X 2I-2-4.

82. "Criminal contra Juan Carpintero por haber forzado a una mujer casada", AHPBA, Juzgado del Crimen, 34-5-98-I (I83I).

83. The words of the victim and those of her eight-year-old niece carried, in the appreciation of the judges, the same weight as Carpintero's words. And the evidence (the blooded knife and pillow, and the sumario made in the previous case) weighed in favor of the victims' arguments. 
right of the victim to defend herself from physical attack by a stronger man, as well as procedural rules as to what constituted proper evidence, led the judges to side with the lower-class female. The publicity surrounding the event also played a role. Once denounced, rape had to be punished if the family order was to be sustained.

Carlos Mayo has studied how in the Buenos Aires frontier, kidnapping women and eloping were the two most common ways of forming sexual partnerships. ${ }^{84}$ These types of relationship involved a significant degree of coercion of women but, at the same time, they evidence the lack of control of male heads of households over their female partners. Once the woman escaped (voluntarily or not) with another man, her husband had very few means to recover her. As with runaway slaves or apprentices, females who escaped became "their own masters". This had as much to do with the limitations of state power in enforcing private male "rights" as with the fluidity of social relations at the frontier. In a social environment characterized by migration and occupational mobility - where migrants "married" in one town and settled in the next - the very institution of marriage was in flux. ${ }^{85}$ Sustaining this remarkable population mobility across the pampas were active markets for land and labor at the frontier. The availability of jobs for male peons and female servants on ranches and farms, as well as the possibility of occupying land through a variety of contractual forms, kept the migrants coming.

Reactions of economic agents to coercive policies also conditioned the viability of certain types of public policy, influencing in the end the state's repertoire of coercion. Food shortages produced by mass levas (forced recruitment) raised the social and political cost of such policies to intolerable levels. Forced military recruitment during the war with Brazil (I825-I828) produced dramatic market effects. The need to raise an army in a short period of time led to one of the most violent, indiscriminate, and massive campaigns of forced recruitment, causing panic and widespread rejection among the peasant population of Buenos Aires province. ${ }^{86}$ In order to escape the forced draft thousands of peasants (labradores and criadores) fled to the woods, to the Delta islands, to the south, or simply hid in the bushes. J.M. Beruti, a contemporary observer, noted that after one of these drafts (August 1826) the countryside appeared "almost without men". This exodus pre-

84. Carlos Mayo, "Amistades ilícitas: Las relaciones extra-matrimoniales en la campaña bonaerense, 1750-1810”, Cuadernos de Historia Regional, I:2 (April 1985), pp. 3-9.

85. José Mateo, "Migrar y volver a migrar. Los campesinos agricultores de la frontera bonaerense a principios del siglo XIX", in J.C. Garavaglia and J.L. Moreno (eds), Población, sociedad, familia y migraciones en el espacio rioplatense. Siglos XVIII y XIX (Buenos Aires, I993), pp. I23-I48.

86. The same situation was reported in the province of Córdoba in I8I3. The leva had the effect of making men disappear, making it almost impossible for agricultural districts to harvest the grain. Horacio J. Pianetto, La situación social de la campaña de Córdoba durante el periodo de la revolución, I810-I8I4 (Córdoba, 1968), pp. 45-48. 
vented rural communities from harvesting the grain. As a result, there were considerable shortages of food after the draft (the price of bread rose significantly). ${ }^{87}$ Though no food riots ensued, the government learnt the harsh reality of peasant resistance: forced recruitment could affect the market for agricultural produce, triggering shortages of food that compounded the initial discontent. ${ }^{88}$

Market forces also affected the government's Indian policy. In I856 the settlers of Patagones (a frontier town) protested against a recent regulation by the government that prohibited the purchase of cattle from the Indians. In order to make peace with cacique Yanquetruz, the colonists had recognized possession rights on the cattle appropriated by his tribe and were actually purchasing their own cattle at a price they considered fair. ${ }^{89}$ Defying the government's policy of intimidating Indian tribes into signing peace treaties, the colonists traded directly with the Indians. Indeed, they had signed a separate treaty on commerce with Yanquetruz. For the colonists, acceptance of this peculiar form of commerce was a question of survival: the quite real possibility of shortages of food. Unlike the government, the colonists assumed that Indian peoples, acting as rational economic agents, would respond to the law of supply and demand and send their cattle to Chile or to neighboring provinces if the prohibition advocated by the government was enforced.

If the government's frontier policy became captive to private agreements between residents and indigenous tribes, because of the logic of scarcity other institutions also felt the pressure of market forces. Domestic slavery, policing, and military life - three activities based upon coercion - showed a gradual adaptation to the mobility demanded by the labor market. Due to the attraction of high wages paid to free labor, slavery became quite a peculiar institution. Owners hired out their slaves for wages, receiving part of the wages in return. Slaves, having moved out of their master's residences, found little supervision from their new bosses (usually bakers, smiths, brickmakers, small merchants, and widows) and were practically "free" in all regards. In practice, slavery became an obligation to pay a daily or monthly amount to masters. ${ }^{90}$ To this extent, masters came to depend upon the fluctuations of the labor market.

87. J.M. Beruti, Memorias Curiosas, quoted in Tulio Halperin Donghi. Guerra y finanzas en los origenes del Estado argentino (I79I-I850) (Buenos Aires, 1982), pp. I58-I59.

88. After I 828 governments seemed to have learned this lesson. Though they did not abandon forced drafts, they made more restricted use of them, combining levado soldiers with others hired for a wage, the so-called enganchados.

89. Comandante Militar de Patagones to Ministro de Guera Bartolomé Mitre, Patagones, 6 October 1856, AGN X 19-6-I.

90. The transfer of slaves into the labor market, as suppliers of labor services, did not force down the wages for free laborers. The growth of labor demand was so rapid that wages continued to rise. 


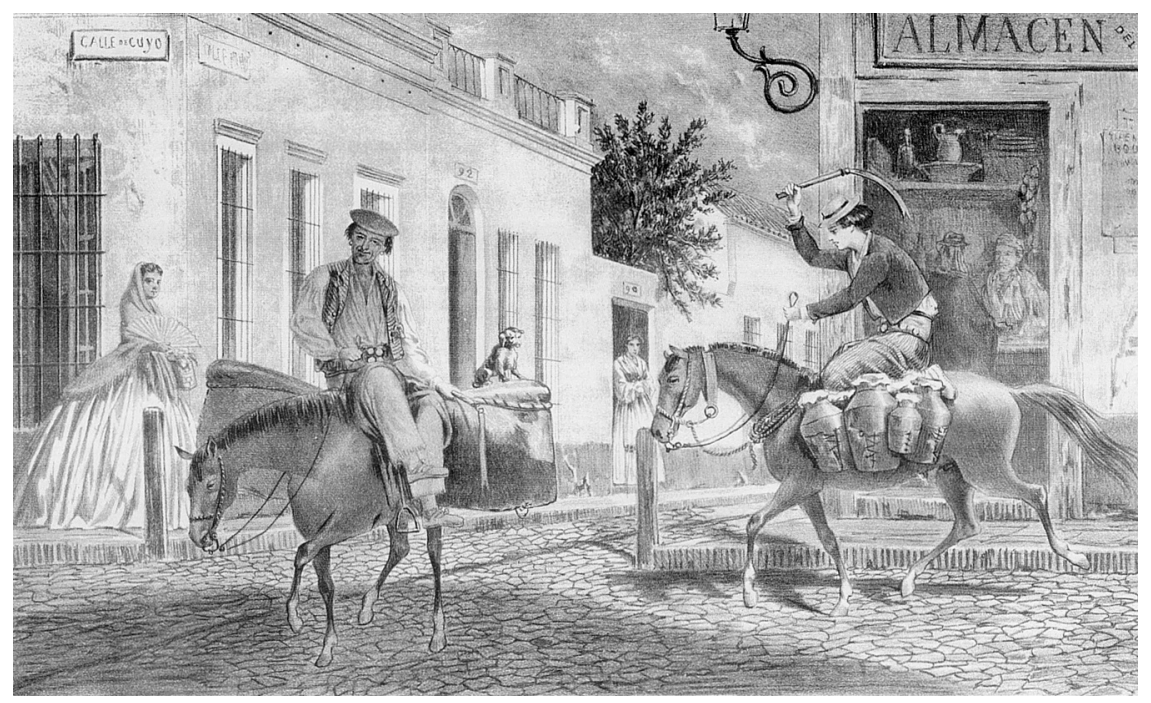

Figure 5. Leon Palliere, Lechero y Panadero, (lithograph, I86os). During the post-Independence period, the streets of Buenos Aires city were the site for the social interaction of the subaltern classes. African, Basque, and Creole vendors (in this case a milkman and a bread peddler) shared the experience of the market place, regardless of their free or unfree condition.

From Leon Palliere, Escenas Americanas (Buenos Aires: Litografia Pelvilian, I864)

Under the Rosas administration the state expanded its reach over the countryside, as a result of the increase in the number of rural justices of the peace, and of the greater control exercised by the governor. But even under a regime that centralized judicial decisions, local justices had to find negotiated solutions to the problem of social order. The inability of JPs to pay market rates to their policemen meant that the enforcement of laws had to depend on the goodwill of local residents. Just to arrest thieves, deserters, and other "undesirables", local justices had to request the voluntary cooperation of vecinos (neighbors), for the office rarely had more than one policeman (alcalde or teniente alcalde). The influence of local residents upon the outcome of local justice (that justice was not related to "national" affairs of war or politics) was made evident in penal practice. Fines and short-term arrests constituted the most common punishments applied to neighbors. Nonresident itinerant workers and other "vagrants", on the other hand, were punished with greater severity, namely long-term service in the army.

Within military barracks, contractualism was rampant during the Rosas period. As all soldiers, whether recruited by force, monetary incentives, or patriotic rhetoric, joined the army's payroll, there were innumerable opportunities for arguments between officers and soldiers. Delays in pay, misuse of government funds, and illegal appropriation of rations were the most 
common grievances voiced by the soldiery. ${ }^{9 \mathrm{I}}$ The civil wars had accustomed soldiers to economic rewards that they tried to maintain during peacetime. Individually, soldiers bargained for leave, for auxilios in uniforms and money, for vicios (tobacco and yerba), and for other material benefits - new uniforms, for instance. Collectively, soldiers threatened their officers with desertion, or with service under a different commanding officer, in order to further their demands for the reduction of verbal and physical abuse or for the elimination of "private work".

The existence of labor shortages, the practice of certain institutional rules, shared notions about rights, peer condemnation, and a particularly low tolerance towards punishment seem to have placed limits on the extent of coercion in these different environments (the ranch, the justice system, the household, the army). Market forces, in the form of incentives, pressures, or rhetorical power, influenced the exercise of coercion. The examples provided show that across a variety of social fields the means of coercion available to the dominant were not all that productive of obedience and deference. Sexual abuse, flogging, temporary confinement, and threats of forced conscription lose part of their persuasive force if that violence is not reinforced by the complicity of class and political power, and if the subaltern classes do not accept the logic implied in the coercive message of the powerful. The very possibility of this type of everyday, subaltern resistance lies in the viability of contractual relationships that entail a great degree of occupational and spatial mobility.

\section{CONCLUSION}

Historians of subaltern life and consciousness are often confronted with the necessity to deconstruct and problematize certain meta-narratives of the nation. In post-independent Argentina, liberal historiography has presented the emergence of the nation state as the successful coercion of rebellious and irrecoverable subalternities (gauchos, pampa Indians, and black workers). The enhancement of the sphere of bourgeois freedom was predicated upon the suppression of internal, regional dissent, the pacification of intra-elite conflicts, and the "civilization" of rural culture. Implicit in this

9I. As S. Gayol has pointed out for the period I870-1890, efforts to modernize the police force were hindered by a chronic shortage of laborers. Due to high wages in other occupations, the police were unable to retain their best men. During the harvest season, the depletion of men acquired catastrophic proportions. The size of the effective force was always smaller than the number of posts available, and the quality of men lower than desired. High rates of labor turnover made the instruction and disciplining of policemen an illusory goal. An illiterate force, with little knowledge of the streets they patrolled - and often without knowledge of the weapons they used could hardly guarantee public order on the streets. Sandra Gayol, "Entre lo deseable y lo posible. Perfil de la Policía de Buenos Aires en la segunda mitad del siglo XIX”, Estudios Sociales (Santa Fé), 5, Io (1996), pp. I27-I3I. 
narrative is the notion that the process of state formation required the exercise of certain forms of coercion (forced conscription, suppression of regional uprisings, and the extermination of belligerent tribes). And that the enhancement of bourgeois freedoms resulted from a change of political regime (the emergence of a centralized nation state and a constitutional government). This traditional narrative leaves out many situations of everyday coercion generated in army regiments, households, prisons, on farms and ranches, etc. By focusing on the military, political, and legal armature of nation-building, liberal historians have managed to suppress the disturbing presence of the subaltern: soldiers, women, Blacks, small-scale criadores who collectively contributed to construct the "liberties" on which the nation was founded.

In my work over the last ten years or so, it has been my goal to replace this unidirectional narrative with a complex history of distinct subjectivities struggling for incorporation and autonomy within the context of significant changes in terms of state formation and the development of market relations. In my previous work, I have challenged traditional interpretations of the estancia economy, reinterpreted the meaning of Rosista federalism, examined the contention between soldiers and officers within army regiments, and studied the interactions between justices of the peace and rural subalterns. Other scholars have worked on the question of family discipline, master-slave discipline, and gender relations. In this essay I wanted to summarize all these findings with the help of a construct that could account for the diversity of "situations of coercion". In fact, this essay presents a more inclusive and comprehensive vision, one that reconciles different spaces of contention and multiple pairs of subaltern-dominant relationships.

This form of representing the problem of coercion - not the only heuristic possibility, to be sure - stems from a reflection about the market and state transitions in post-Independence Buenos Aires province. My attempt to incorporate multiple forms of coercion in various institutional settings addresses the claims of a particular historiographical legacy. This tradition has presented the military-political domain as the privileged territory for the narration of the emergence of the nation, and the private economic and domestic spheres appear as unproblematic and nonconflictive. For this historiography, the construction of a modern nation has resulted in the expansion of the domain of freedom as a simple result of the resolution of interregional conflicts, the suppression of inconvenient subalternities, and the arrival of European immigrants (the "civilizatory" input). By contrast, I have argued for the need to reexamine the question of coercion and freedom in a variety of social fields, relocating the voices and actions of the subaltern in the context of an across-the-board contestation of authority and power. To relocate a series of microstories of interaction between dominant and 
subaltern actors into the field of national history, I have suggested a convenient expedient: the construct of "repertoires of contention".

If there is a basic inference we can derive from the general mapping of coercion in the Rosas period, it is that coercion was unevenly distributed in terms of institutions and victims. If one had to rank institutions according to their power to coerce, the political machinery of the state and the army would be first, the justice system would follow closely, and the estancia and the household would rank low, as institutions with a high degree of "contractual" relations. If this exercise of classification were to be extended to the subjects or victims of coercion, clearly the degüello of Indian elders would be top of the list, together with the practice of exhibiting unitario heads on poles. The servitude of Indian children appropriated by soldiers and given to ranchers would rank close, together with the whipping of insubordinate slaves in the Cárcel Pública. The transportation of prisoners in irons would follow. If coercion had to be ranked according to its volume or extensiveness, then the numbers of peasants and itinerant workers judicially sentenced to long terms of service in the army would be the most important type of coercion. At the other extreme we would have to place peons restrained on ranches against their will, or women sent to the frontier for "immoral behavior", for these constituted infrequent coercive situations.

"Institutional contexts" do not seem to be immune to the social, political, and economic transformations of the period. The increased mobility of working people, the gradual erosion of slavery, and the rising demand for laborers triggered by a bonanza in the ranching economy seem to have limited the menu of coercion available to household heads, ranchers, military commanders, judges, and government authorities. Individuals closer to government and to the politics of Rosismo could, however, exercise some forms of violence and coercion that were quite independent of these transformations. In fact, the violence against unitarios and indigenous peoples appears to have followed a different "logic", one predicated on the duality extermination/assimilation, a duality that admitted little room for transactions. And, since the war against those "enemies" required the preservation of forced conscription, male peasants and laborers suffered additional doses of non-negotiable, systematic coercion.

A second important inference would be that the "purpose" or "function" for which an institution applies coercion is quite relevant for determining the diversity of forms and the intensity of coercive power - or the amplitude of its repertoire of coercion. The military's demand for new recruits produces more widespread and less negotiable forms of coercion than the military's pursuit of well-disciplined soldiers. In the former case, the state puts all its muscle to work, activating the coercive power of justices, military officers, rural policemen, and special commissioners. In the latter case, soldiers and officers can negotiate the outcomes in more restricted spaces - 
whether whipping, a cut in wages, or additional work results from an act of indiscipline or theft will depend on these micro-negotiations..$^{92}$ In this comparison, it is the intensity and regularity of coercion that changes.

Another comparison, that between a rancher trying to coerce the mobility of peons and a member of the Mazorca trying to intimidate a unitario family, can illuminate another dimension of the uneven distribution of coercion. Here, what changes is the scope of the repertoire of coercion. The rancher has a much more restricted menu of options, for he has learnt from experience that "protection" and credit had a limited impact on the decision of workers to stay and that physical and verbal abuse produce quite opposite results than intended. The Mazorquero, on the other hand, knows that in the climate of terror generated through rumor, any act of violence would be quite effective (daubing the door of the family house, searching and destroying books and papers, interrogating friends of the target person, confiscating property, etc.). Here, the main difference is the resources at the disposal of ranchers and Mazorqueros.

A third observation refers to the relationship between coercion and incentives. Most power-holders are able to opt to use incentives instead of coercion. Ranchers could resort to higher wages and sharecropping contracts, army recruiters could offer enganches and additional auxilios, household masters could extend "promises of freedom" to slaves or raise the wages of libertos and other servants. The degree of substitutability between coercion and incentives varies according to the resources of each institutional context. Justices of the peace, for instance, have almost no financial resources and a very limited capacity to tax: their ability to use incentives, then, is almost negligible. They had to use various forms of coercion. Ranchers instead possessed financial and real assets (cattle, sheep, money, clothes) that could be used to attract the workforce and lacked the power to arrest, sentence, or punish. Army officers had both types of resources: they could offer uniforms, horses, and weapons to new recruits, or distribute "leave to work" and auxilios among the soldiery, but they could also order the arrest and flogging of indisciplined soldiers.

We can think of yet another way of ordering the forms of coercion prevalent in the Rosas period: the different degree to which society tolerated distinct forms of violence. The concept of repertoires of coercion is not very helpful in this regard, for it does not relate to the issue of reception. We know, nonetheless, that during the Rosas period people regarded some forms of violence as more repulsive than others. The highest degree of toleration (amongst federalist communities) was for the violence exerted

92. We are assuming here that both the government and the military are subject to the same low degree of institutionalization, that officers and functionaries do not pay much attention to institutional rules. 
against unitarios. ${ }^{93}$ The definition of the political and military enemy as a person without fatherland, reason, or morality, made the beheading of them a quite appropriate form of violence. Similarly, army raids against enemy tribes were also considered by most cristianos as a deserved form of punishment, as a retribution for Indian malones or "invasions". Less tolerated, and indeed highly criticized by the population of Buenos Aires, was the shooting in a public square of Indian prisoners. Executions, when used as exemplary punishment for murderers, received little criticism from "neighbors". When, on the contrary, the same type of execution was applied against pregnant women or children, society's outcry was loudly heard. ${ }^{4}$

Compared with the Rosas era, the following period showed a reduction in certain forms of coercion. In the areas of military recruitment and political competition, less coercive means were utilized. With regard to other institutional environments, the evidence is more ambiguous. The justice system was reconstructed with a greater regard for procedures, evidence, and jurisprudence, but, on the other hand, exemplary executions increased. Greater individual liberties for immigrants coincided with growing conflicts between the army and pampa Indians, reaching peaks of violence in I855 and I857. The household liberated itself of slavery or other related forms of personal dependence but, at the same time, the arrival of European immigrants brought about more rigid family norms, particularly those related to the control of women's bodies and labor. We lack evidence about the fate of children in this post-dictatorial epoch. It is likely that the general freedom of movement for rural workers was not altered until the enactment of 1865 Rural Code, but we need more information to confirm this impression.

A change of regime (the transition from dictatorship to oligarchic parliamentarism) was at the root of these changes in coercion. But due to the presence of institutional logics and different degrees of resistance, not all fields of power experienced the same reduction in the level of coercion. A third factor has been shown to have a pervasive and constant influence on the formation of institutional repertoires of coercion: the attraction of markets. Acting within and without institutional contexts, market forces imposed severe limits on the ability of institutions and power-holders to exercise coercion. The generalized scarcity of labor, combined with a widespread contractualism among the popular sectors, contributed to make the functioning of coercive mechanisms difficult. Fields of power such as city policing, military discipline, White-Indian relations, and local governments felt the pressure of the "attraction of markets". Moreover, as our examples

93. The exposure of the bodies of unitarios on the streets seemed to have caused alarm among the elite of the city, but not so much among the population at large, the mass of people supporting the federalists.

94. The story of the execution of Camila O'Gorman and her fiancé, the priest Ladislao Gutierrez, made evident this difference in society's toleration of violence. The dictator was surprised by the strong opposition the execution awakened, as if the moral chord of society had been touched. 
have shown, the tendency, already distinct during the Rosas period, for coercion to turn into contract - a switching of means used by power-holders in the very process of establishing authority - intensified after the fall of Rosas. Though not yet a "market society", by 1865 Buenos Aires province possessed some ingredients of a market culture.

In this culture, some forms of violence became intolerable, the reminder of a foregone dictatorial era (political assassinations and confiscations), while others (public executions, raids on indigenous tribes) turned into accepted and necessary means of maintaining peace and order. Political violence, Indian policy, and penal retribution form part - like violence within the household and on the ranch - of the general economy of coercion. We need ways to compare, evaluate, and possibly to measure such an economy, productive of multiple forms of violence. Concentrating on certain modes of organizing labor (slavery, peonage, convict labor) leaves many forms of coercion unexamined, their interactions overlooked. The use of repertoires of coercion has enabled us to take a wider view of the phenomenon under consideration. This conceptual aid has helped us organize the qualitative evidence available for a given regime and society, without reducing the complexity of power relations or the variety of coercive mechanisms. In addition, repertoires of coercion are windows into the study of the relationship between markets and coercion. Being transected by market incentives and other noncoercive mechanisms, institutional repertoires show already the traces of a society's transition towards a market culture. The contractualism of power relations, the translation of work time into money, the association of individual rights with mobility, and the low degree of tolerance towards corporal punishment, cannot be separated from the experience and knowledge gathered in institutional contexts about the possibilities and limits of coercion in modifying subalterns' actions and conduct. This experience and knowledge we have called, reversing Tilly's argument, "repertoires of coercion". 